\title{
The Caddoan Ceramics from the Gray's Pasture Site (41HS524), Harrison County, Texas
}

Timothy K. Perttula

Heritage Research Center, Stephen F. Austin State University

Bo Nelson

Heritage Research Center, Stephen F. Austin State University

Mike Turner

Follow this and additional works at: https://scholarworks.sfasu.edu/ita

Part of the American Material Culture Commons, Archaeological Anthropology Commons, Environmental Studies Commons, Other American Studies Commons, Other Arts and Humanities Commons, Other History of Art, Architecture, and Archaeology Commons, and the United States History Commons

Tell us how this article helped you.

This Article is brought to you for free and open access by the Center for Regional Heritage Research at SFA ScholarWorks. It has been accepted for inclusion in Index of Texas Archaeology: Open Access Gray Literature from the Lone Star State by an authorized editor of SFA ScholarWorks. For more information, please contact cdsscholarworks@sfasu.edu. 


\section{The Caddoan Ceramics from the Gray's Pasture Site (41HS524), Harrison County,}

Texas

\section{Creative Commons License}

\section{(c) (1) (8)}

This work is licensed under a Creative Commons Attribution-NonCommercial 4.0 International License 


\title{
THE CADDOAN CERAMICS FROM THE GRAY'S PASTURE SITE (41HS524), HARRISON COUNTY, TEXAS
}

\author{
Timothy K. Perttula, with contributions from Bo Nelson and Mike Turner
}

\section{INTRODUCTION}

This paper discusses the Caddoan ceramics recovered during the 1992 Northeast T'exas Archeological Society Field School at the Gray's Pasture site (41HS524) on Clark's Creek (see Keller 1992a), a few miles south of Hallsville, Texas (Figure 1) and about 2 miles from the Sabine River floodplain. During the course of the excavations, an extensive Caddoan settlement was documented on a series of knolls on a broad terrace landform overlooking the Clark's Creek floodplain (Figure 2), and each of those areas contains Caddoan ceramics. Most notably, a dense concentration of Caddoan ceramics, as well as two burials with whole ceramic vessels, was encountered in the northwestern part of the site, and the majority of the ceramics are from this area.

The four site areas include Area I (Unit 1) on a knoll at the northeastern part of the site, Area II on the terrace at the far eastern end of the site (Units 3 and 7), Area III on the crest of the landform in the central and southwestern part of the site (Units 2, 5, and 6), and Area IV in the northwestern part of the site (Units 8, 8X, 10-16) (see Figure 2). Unit 4 belongs in Area III, and contained a number of sherds, but these artifacts are missing (Mike Turner, 1996 personal communication), except for one plain sherd. Unit 9, in the southeastern part of the site (see Figure 2) only had a few plain sherds.

A total of 2352 sherds and four vessels comprise the Caddoan ceramic assemblage from Gray's Pasture. This includes 1740 plain body and base sherds (Table 1), 61 plain rims, and 551 decorated rim and body sherds (Table 2). About $81 \%$ of the sherds are from Area IV, with $9.3 \%$ of the sherds from Area III.

There are 71 decorated rim sherds and 480 decorated body sherds (not including 11 red slipped sherds). The plain/decorated sherd ratio is 3.27 for the site as a whole, and ranges from 3.21 to 3.69 by site area. This is consistent with other pre-A.D. 1200 Caddoan sites in the Red, middle Sabine, and Neches-Angelina river basins, where such sites have plain/decorated sherd ratios that range between 2.97-4.80 (Perttula 1999a). Thirteenth and 14th century sites in these areas have plain/decorated sherd ratios of 1.30 1.61, and Late Caddoan sites dating between ca. A.D. 1450-1650 have ratios of 0.56I.03. Through time, more Caddoan vessels are decorated, and vessels are more completely covered with decoration, rather than having the decoration confined primarily to the rim. 


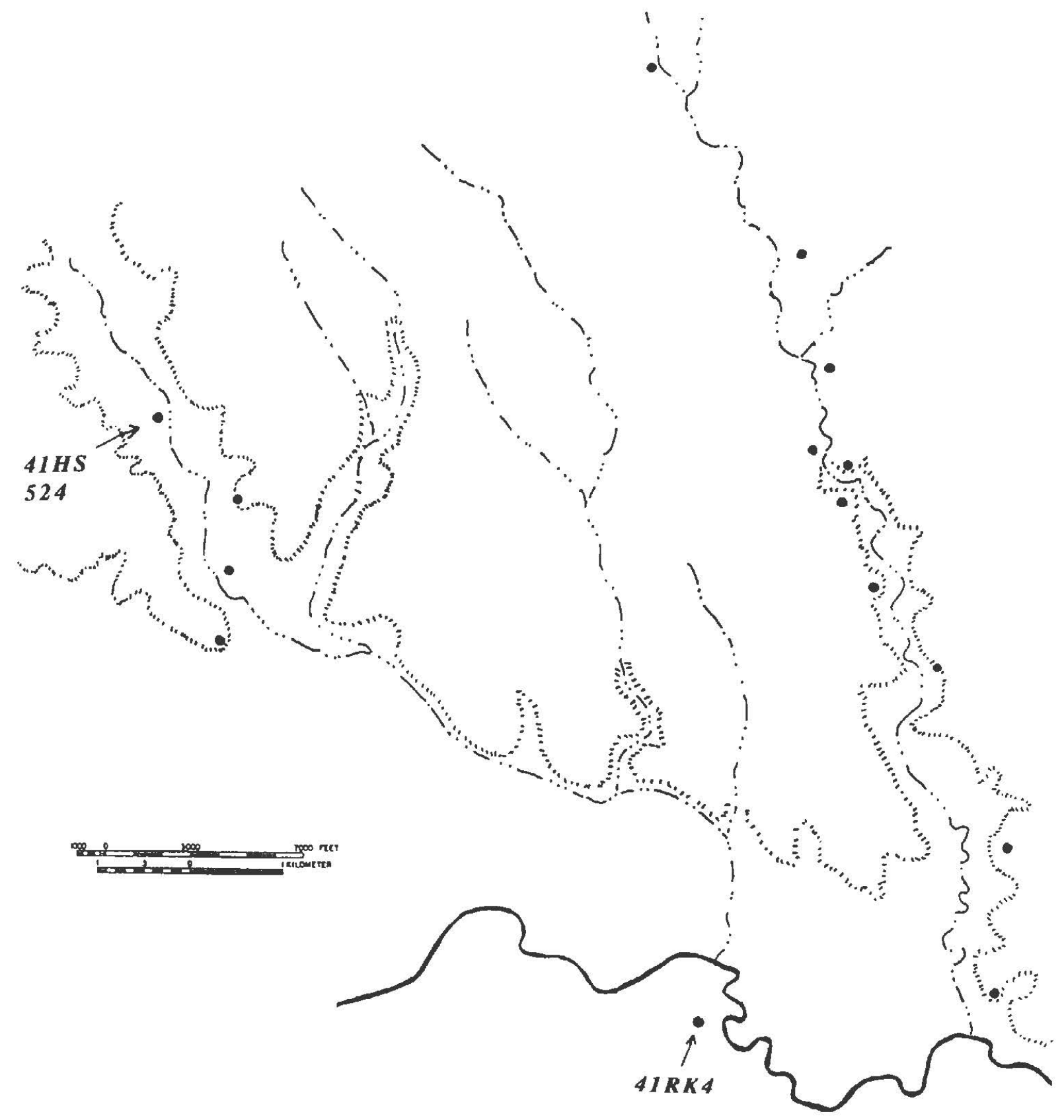

Figure 1. The Gray's Pasture (41HS524), Hudnall-Pirtle (41RK4), and other Early-Middle Caddoan sites in the South Hallsville stretch of the middle Sabine River basin. 


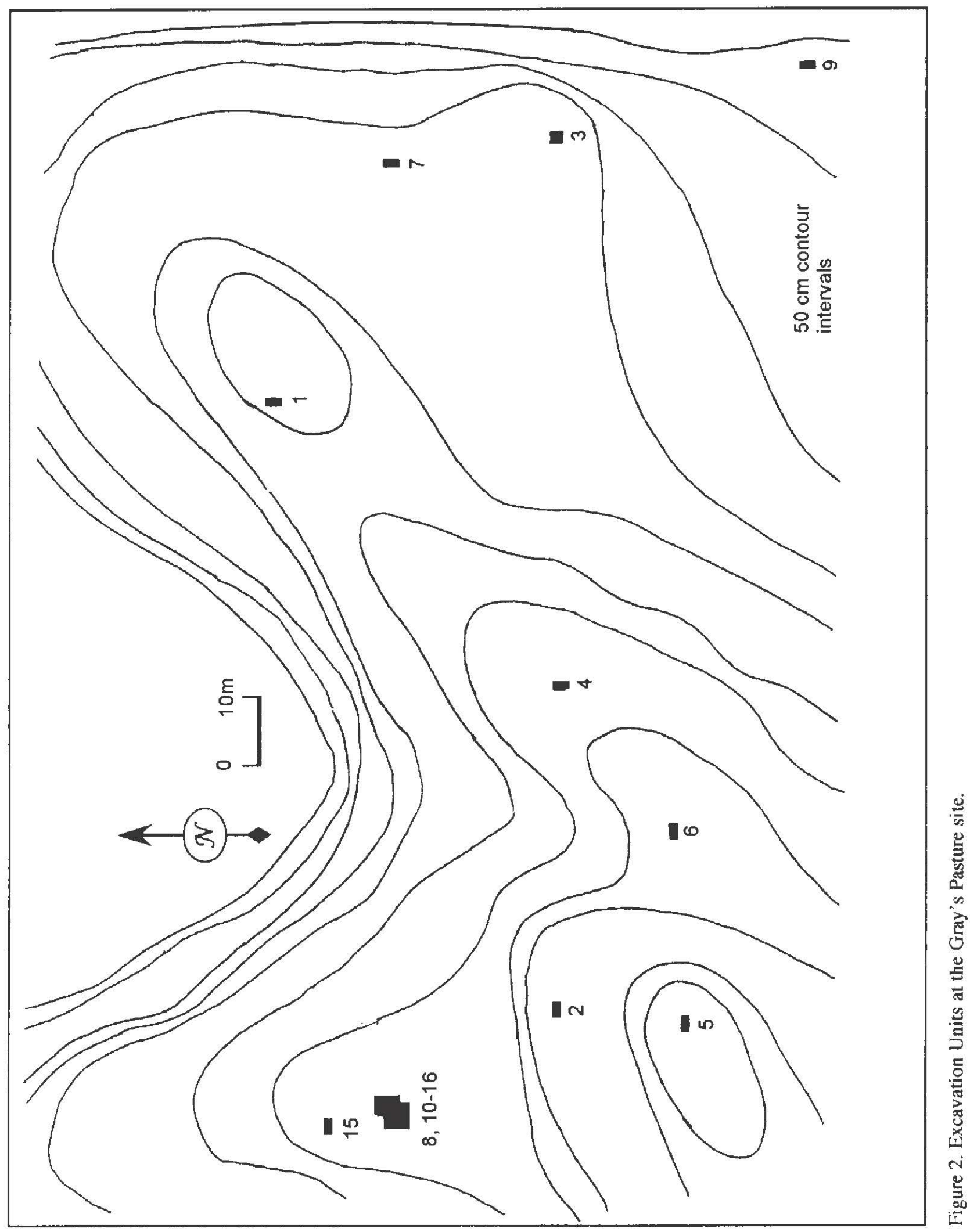


Table 1. Plain Body/Base Sherds from the Gray's Pasture Site

\begin{tabular}{|c|c|c|c|c|}
\hline \multicolumn{3}{|l|}{ Unit/I evel } & \multicolumn{2}{|l|}{ Temper Classes } \\
\hline & Grog & Grog-Bone & Grog-Grit-Bone & Grog-Grit \\
\hline $\begin{array}{ll}\text { Unit } 1 \text { lv. } 1 \\
\text { lv. } 2 \\
\text { lv. } 3 \\
\text { lv. } 4 \\
\text { lv. } 5 \\
\text { lv. } 6 \\
\text { lv. } 7-11 \\
\text { Subtotal }\end{array}$ & $\begin{array}{l}3 \\
2 \\
10 \\
10 \\
1 \\
4 \\
- \\
30\end{array}$ & $\begin{array}{l}4 \\
2 \\
2 \\
3 \\
- \\
- \\
- \\
11\end{array}$ & $\begin{array}{l}- \\
\overline{2} \\
2 \\
3 \\
1 \\
- \\
- \\
6\end{array}$ & $\begin{array}{l}- \\
3 \\
2 \\
4 \\
2 \\
3 \\
- \\
14\end{array}$ \\
\hline Subtotal & 30 & 11 & 6 & 14 \\
\hline $\begin{aligned} \text { Unit } 2 & \text { lv. } 1 \\
& \text { Iv. } 2 \\
& \text { Iv. } 3 \\
& \text { Iv. } 4-5\end{aligned}$ & $\begin{array}{l}16 \\
11 \\
3 \\
-\end{array}$ & $\begin{array}{l}- \\
1 \\
-\end{array}$ & $\begin{array}{l}1 \\
- \\
- \\
-\end{array}$ & $\begin{array}{l}8 \\
7 \\
5 \\
-\end{array}$ \\
\hline Subtotal & 30 & 1 & 1 & 20 \\
\hline $\begin{aligned} & \text { Unit } 3 \text { lv. } 1 \\
& \text { lv. } 2 \\
& \text { lv. } 3 \\
& \text { lv. } 4 \\
& \text { lv. } 5 \\
& \text { lv. } 6 \\
& \text { lv. } 7 \\
& \text { lv. } 8-11 \\
& \text { Subtotal }\end{aligned}$ & $\begin{array}{l}4 \\
2 \\
3 \\
2 \\
1 \\
1 \\
- \\
- \\
13\end{array}$ & $\begin{array}{l}2 \\
2 \\
- \\
- \\
- \\
- \\
- \\
4\end{array}$ & $\begin{array}{l}1 \\
- \\
- \\
- \\
- \\
- \\
- \\
- \\
1\end{array}$ & $\begin{array}{l}3 \\
3 \\
2 \\
1 * \\
2 \\
1 \\
1 \\
- \\
13\end{array}$ \\
\hline $\begin{array}{r}\text { Unit } 4 \text { lv. } 1 \\
\text { lv. } 2 \\
\text { lv. } 3 \\
\text { lv. } 4 \\
\text { Subtotal }\end{array}$ & $\begin{array}{l}? \\
? \\
- \\
- \\
-\end{array}$ & $\begin{array}{l}? \\
? \\
- \\
- \\
-\end{array}$ & $\begin{array}{l}? \\
? \\
- \\
-\end{array}$ & $\begin{array}{l}? \\
? \\
- \\
1\end{array}$ \\
\hline $\begin{aligned} & \text { Unit } 5 \text { lv. } 1 \\
& \text { lv. } 2 \\
& \text { Iv. } 3 \\
& \text { Iv. } 4 \\
& \text { 1v. } 5-6\end{aligned}$ & $\begin{array}{l}34 \\
13(1)^{*} \\
1 \\
- \\
- \\
48\end{array}$ & $\begin{array}{l}9 \\
3 \\
- \\
- \\
- \\
12\end{array}$ & $\begin{array}{l}7 \\
4 \\
- \\
- \\
- \\
11\end{array}$ & $\begin{array}{l}19 \\
12 \\
1 \\
2 \\
- \\
34\end{array}$ \\
\hline $\begin{array}{r}\text { Unit } 6 \text { lv. } 1 \\
\text { lv. } 2 \\
\text { lv. } 3 \\
\text { lv. } 4 \\
\text { lv. } 5 \\
\text { lv. } 6 \\
\text { lv. } 7 \\
\text { lv. } 8\end{array}$ & $\begin{array}{l}? \\
? \\
12 \\
4 \\
1 \\
- \\
- \\
-\end{array}$ & $\begin{array}{l}? \\
? \\
2 \\
1 \\
- \\
- \\
1 \\
-\end{array}$ & $\begin{array}{l}? \\
? \\
2 \\
2 \\
- \\
1 \\
1 \\
-\end{array}$ & $\begin{array}{l}? \\
? \\
17 \\
8 \\
6 \\
4 \\
- \\
-\end{array}$ \\
\hline Subtotal & 17 & 4 & 5 & 35 \\
\hline
\end{tabular}


Table 1. Plain Body/Base Sherds from the Gray's Pasture Site, cont.

\begin{tabular}{|c|c|c|c|c|}
\hline \multirow[t]{2}{*}{ Unit/Level } & \multicolumn{4}{|c|}{ Temper Classes } \\
\hline & Grog & Grog-Bone & Grog-Grit-Bone & Grog-Grit \\
\hline Unit 7 Iv. 1 & 2 & - & 1 & 2 \\
\hline lv. 2 & - & - & - & - \\
\hline Iv. 3 & - & 3 & 4 & 1 \\
\hline lv. 4 & - & - & 1 & 3 \\
\hline lv. 5 & 1 & - & - & 1 \\
\hline lv. 6-7 & - & - & - & - \\
\hline Subtotal & 3 & 3 & 6 & 7 \\
\hline Unit 8 lv. 1 & 13 & 4 & 11 & 33 \\
\hline lv. 2 & 8 & 1 & 4 & 17 \\
\hline lv. 3 & 6 & - & 6 & 19 \\
\hline lv. 4 & 7 & - & 5 & 8 \\
\hline lv. 5 & 1 & - & 1 & $5(1)^{*}$ \\
\hline lv. 6 & - & - & 1 & - \\
\hline Fea. fill & - & - & 3 & 1 \\
\hline Balk & 2 & - & - & 14 \\
\hline Subtotal & 37 & 5 & 31 & 97 \\
\hline Unit $8 X$ lv. 1 & 3 & 2 & 4 & 21 \\
\hline Iv. 2 & 2 & - & $2(1)^{*}$ & 13 \\
\hline lv. 3 & 9 & - & $2(1)^{*}$ & 24 \\
\hline lv. 4 & 10 & 1 & 7 & 24 \\
\hline Iv. 5 & 3 & - & 3 & 25 \\
\hline Subtotal & 27 & 3 & 18 & 107 \\
\hline Unit 9 lv. 1 & - & - & - & 1 \\
\hline Iv. 2 & - & - & - & - \\
\hline lv. 3 & - & - & $1 *$ & - \\
\hline lv. 4 & - & - & - & 2 \\
\hline Iv. $5-7$ & - & - & - & - \\
\hline Subtotal & - & - & 1 & 3 \\
\hline Unit $10 \mathrm{lv} .1$ & $18(1)^{*}$ & 2 & 9 & 20 \\
\hline lv. 2 & 16 & 1 & - & 16 \\
\hline lv. 3 & 12 & 2 & 10 & 22 \\
\hline Iv. 4 & 4 & - & 3 & 10 \\
\hline lv. 5 & 12 & 1 & $5(1)^{*}$ & 21 \\
\hline lv. 6 & - & - & - & - \\
\hline Fea. II & 3 & - & 6 & 7 \\
\hline Subtotal & 65 & 6 & 33 & 96 \\
\hline Unit $11 \mathrm{lv} .1$ & 10 & 1 & 6 & 17 \\
\hline lv. 2 & 3 & - & 1 & 4 \\
\hline Iv. 3 & 6 & - & 6 & $15(1)^{*}$ \\
\hline Iv. 4 & 9 & 5 & 4 & 18 \\
\hline Subtotal & 28 & 6 & 17 & 54 \\
\hline
\end{tabular}


Table 1. Plain Body/Base Sherds from the Gray's Pasture Site, cont.

\begin{tabular}{|c|c|c|c|c|}
\hline \multirow[t]{2}{*}{ Unit/Level } & \multicolumn{4}{|c|}{ Temper Classes } \\
\hline & Grog & Grog-Bone & Grog-Grit-Bone & Grog-Grit \\
\hline $\begin{array}{r}\text { Unit 12lv. } 1 \\
\text { lv. } 2 \\
\text { lv. } 3 \\
\text { lv. } 4 \\
\text { lv. } 5 \\
\text { lv. } 6 \\
\text { lv. } 7\end{array}$ & $\begin{array}{l}27 \\
19 \\
10 \\
12 \\
- \\
- \\
-\end{array}$ & $\begin{array}{l}4 \\
4 \\
4 \\
3 \\
- \\
- \\
- \\
\end{array}$ & $\begin{array}{l}4 \\
12 \\
8 \\
4 \\
- \\
1 \\
-\end{array}$ & $\begin{array}{l}59 \\
37 \\
25 \\
18 \\
9 \\
3 \\
-\end{array}$ \\
\hline Subtotal & 68 & 15 & 29 & 151 \\
\hline $\begin{array}{r}\text { Unit } 13 \text { lv. } 1 \\
\text { lv. } 2 \\
\text { lv. } 3 \\
\text { lv. } 4 \\
\text { lv. } 5 \\
\text { Subtotal }\end{array}$ & $\begin{array}{l}18 \\
14 \\
15 \\
5 \\
- \\
52\end{array}$ & $\begin{array}{l}2 \\
6 \\
4 \\
1 \\
1 \\
14\end{array}$ & $\begin{array}{l}5 \\
10 \\
12 \\
1 \\
28\end{array}$ & $\begin{array}{l}45 \\
44 \\
57 \\
13(1)^{*} \\
3 \\
162\end{array}$ \\
\hline $\begin{array}{r}\text { Unit } 14 \text { lv. } 1 \\
\text { lv. } 2 \\
\text { lv. } 3 \\
\text { lv. } 4 \\
\text { lv. } 5 \\
\text { Subtotal }\end{array}$ & $\begin{array}{l}6 \\
12 \\
11 \\
9 \\
10 \\
48\end{array}$ & $\begin{array}{l}2 \\
2 \\
2 \\
- \\
1 \\
7\end{array}$ & $\begin{array}{l}2 \\
10 \\
5 \\
5 \\
4 \\
26\end{array}$ & $\begin{array}{l}21 \\
36 \\
27(1)^{*} \\
21(1)^{*} \\
21 \\
126\end{array}$ \\
\hline $\begin{array}{l}\text { Unit } 15 \text { lv. I } \\
\text { lv. } 2-4 \\
\text { lv. } 5 \\
\text { Subtotal }\end{array}$ & $\begin{array}{l}1 \\
? \\
7 \\
8\end{array}$ & $\begin{array}{l}1 \\
? \\
1 \\
2\end{array}$ & $\begin{array}{l}5 \\
? \\
5 \\
10\end{array}$ & $\begin{array}{l}10 \\
? \\
15 \\
25\end{array}$ \\
\hline Surface & - & - & - & $5(1)^{*}$ \\
\hline TOTALS & $474(2)$ & * 93 & $223(4)^{*}$ & $950(6)^{*}$ \\
\hline
\end{tabular}

* Red-slipped

\section{PLAIN BODY AND BASE SHERDS}

The 1740 plain body and base sherds are distributed as follows: Area I, $\mathrm{n}=61$; Area II, $n=50$; Area III, $n=218$; and Area IV, $n=1401$. Four different temper classes are defined in the plain body and base sherds: (1) grog or crushed sherds; (2), grog and bone; (3) grog, grit, and bone; and (4) grog and grit. Grit refers to crushed pieces of hematite deliberately added to the paste, as well as to the occasional addition of larger and angular pieces of quartz sand grains.

Grog-grit-tempered sherds comprise $54.6 \%$ of the plain body and base sherds from the Gray's Pasture site, followed by grog-tempered sherds (27.2\%), grog-grit-bone- 
Table 2. Decorated and Rim Sherds from the Gray's Pasture Site

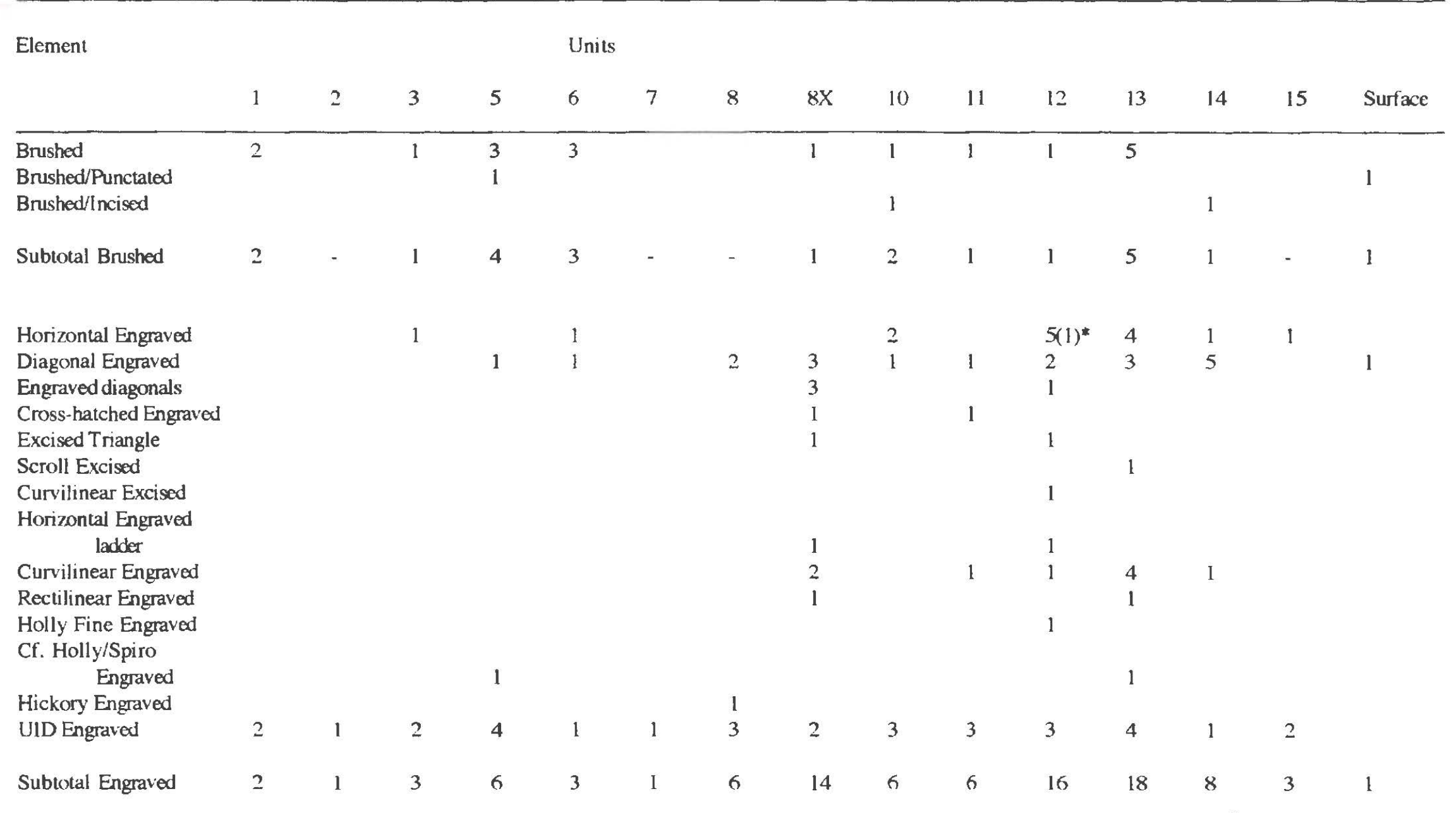


Table 2. Decorated and Rim Sherds, cont.

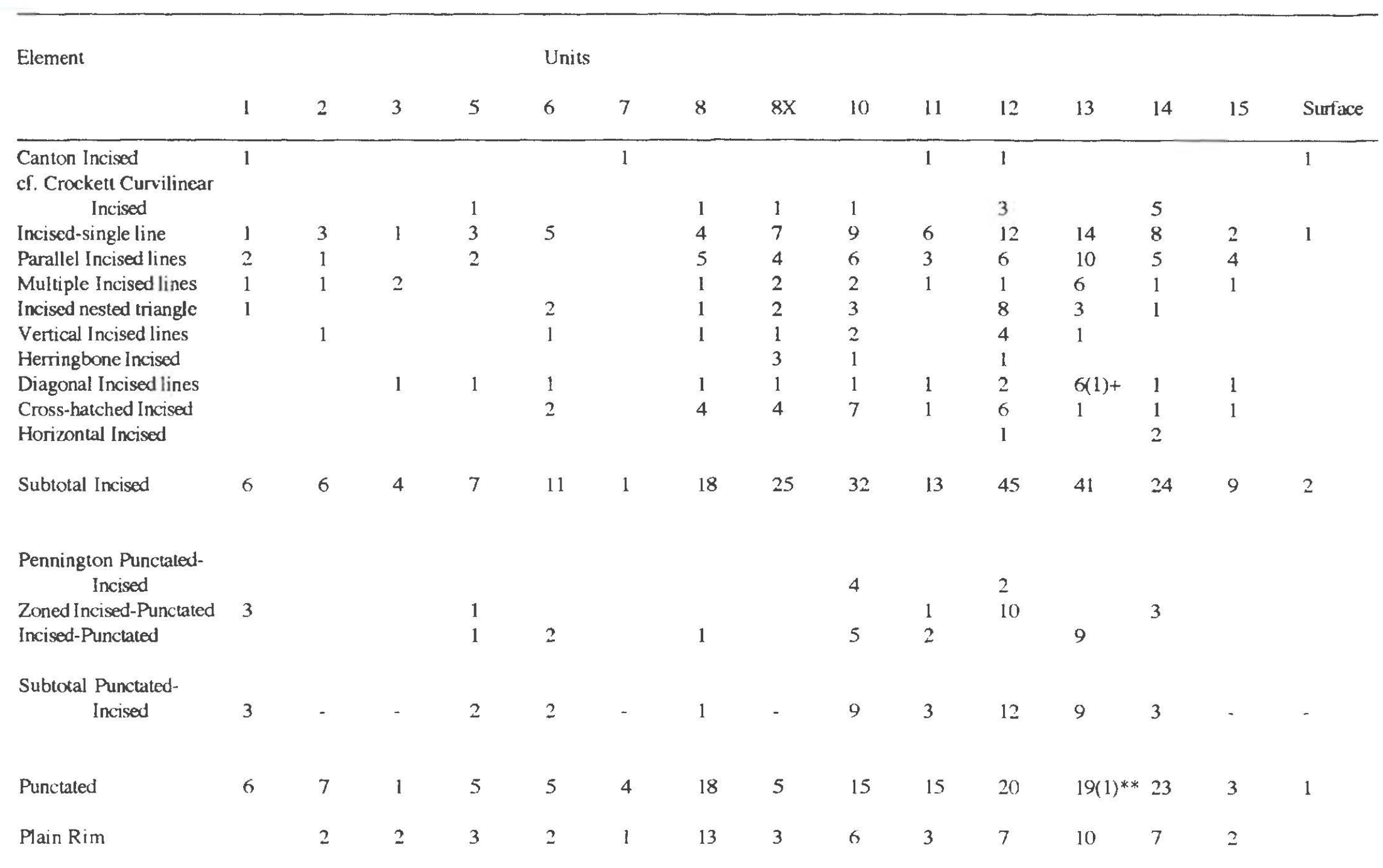


Table 2. Decorated and Rim Sherds, cont.

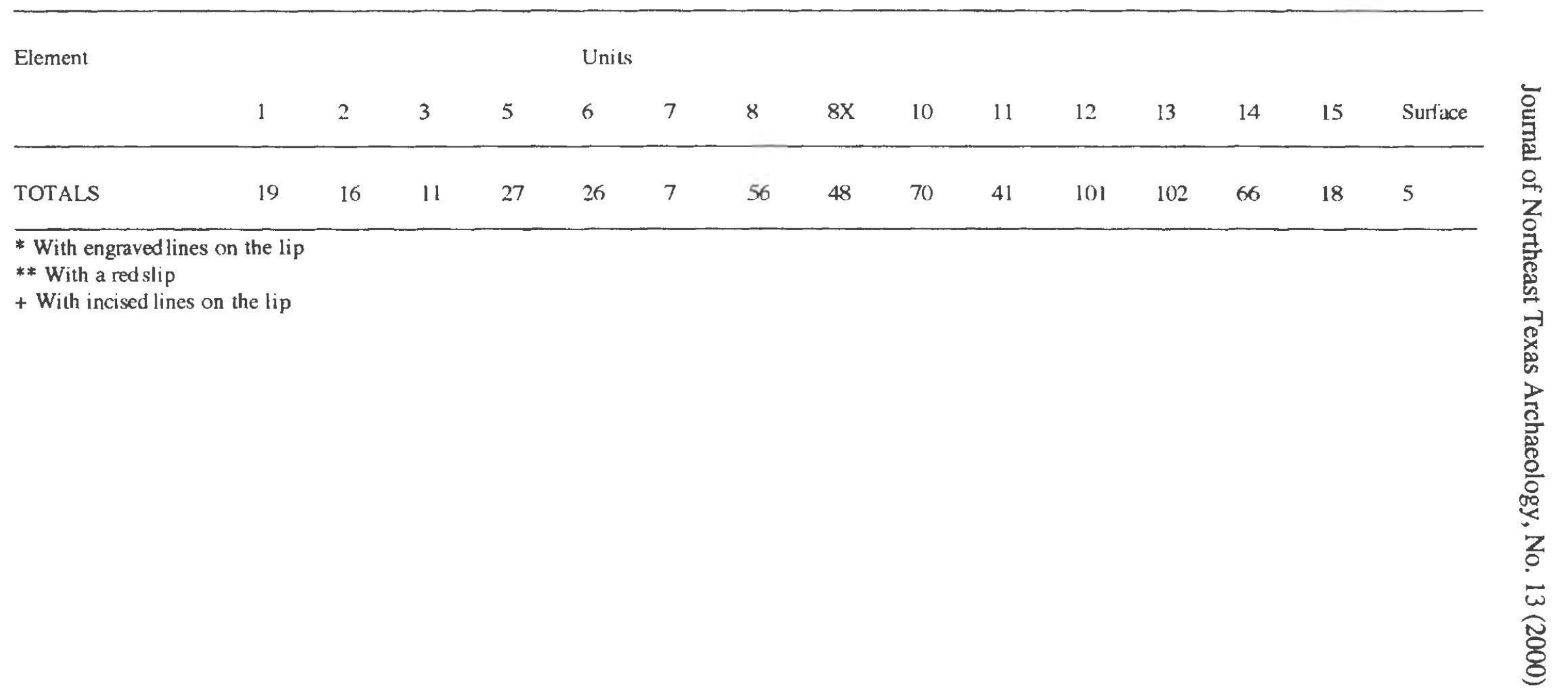


tempered sherds $(12.8 \%)$, and grog-bone-tempered sherds $(5.3 \%)$ (see Table 1$)$. The overall proportion of sherds with burned bone temper is $18.1 \%$.

Grog-grit-tempered sherds are most abundant in the Area IV units (Figure 3), at $58.6 \%$ of the plain body and base sherds, followed by Area III, Area II, and Area I, proceeding from south to east across the site from Area IV. Only $22.9 \%$ of the plain body and base sherds in Area I have grog and grit temper. Conversely, the highest proportions of both grog and grog-bone-tempered sherds occur in Area I, at $49.2 \%$ and $18.0 \%$, respectively, and the lowest percentages of these temper classes are represented in Area IV (23.8\% and $4.1 \%$, respectively). Areas II and III are intermediate between Areas I and IV in the use of grog and grog-bone temper, with $32.0-43.6 \%$ grog-tempered and $7.8-14.0 \%$ grog-bone-tempered sherds. Area IV also has a high proportion of sherds with grog-gritbone tempering $(13.7 \%)$, as does Area II (14.0\%), with only $7.8-9.8 \%$ of the sherds from Area I and III having grog-grit-bone-tempered vessel sherds.

This variation in the use of grog, grit, or bone as temper in the manufacture of ceramics at Gray's Pasture suggest that Area IV can be readily differentiated from Areas IIII. Whether these differences represent temporal and/or functional changes in ceramic manufacture is not known, but it is suspected that both factors come into play. That is to say, that (a) there were changes through time in the choice of tempering materials, and (b) these changes probably represent functional choices in the manufacture of vessels for different cooking and heating uses. We will return to these points later in the paper.

One other difference in the plain body and base sherds between the four site areas is the frequency of red-slipped sherds. While red-slipped sherds are uncommon, as is the case in many middle Sabine River basin Caddoan sites (see Perttula and Cruse 1997), accounting for only $0.69 \%$ of the plain body and base sherds from the site as a whole, they represent $2 \%$ of the body and base sherds in Area II, compared to $0.64 \%$ in Area IV, $0.46 \%$ in Area III, and 0\% in Area I. Grog-grit-bone sherds are more likely to have a red slip $(1.8 \%)$ than either the grog-grit $(0.63 \%)$, grog $(0.42 \%)$, or grog-bone $(0 \%)$ body and base sherds (see Table 1).

\section{PLAIN RIM SHERDS}

There are 61 plain rims in the collection, three in Units 3 and 7 (Area II), seven plain rims in Units 2, 5, and 6 (Area III), and the remaining 51 in Units 8, 8X, and 10-16 (Area IV). The proportion of plain rims to decorated rims (61 plain versus 71 decorated) indicates that many of the vessels at Gray's Pasture were probably undecorated.

Thirty-one of the rims have an indeterminate form because they are very small sherds. The remaining plain rims can be segregated into eight forms, and appear to be from bowls, jars, and bottles.

Rim form A ( $n=1$, Unit 11, level 3) is direct or standing (cf. Brown 1996:Fïgure 212 ), with a rounded lip that is folded to the exterior. The rim is from a small bowl with a $12-14 \mathrm{~cm}$ orifice diameter. It has a red slip, and is $4.5 \mathrm{~mm}$ in thickness. Rim form $\mathrm{B}(\mathrm{n}=2$, one example each from Units 13 and 14, level 4) is direct or standing with a rounded lip, but only a slight exterior fold. The rim thickness ranges from $7.5-9.0 \mathrm{~mm}$, and these two rims are probably from jars. Rim form $C$ includes four sherds from Units 8, 12, and 13 (levels 2 and 3 ). It is everted with a rounded lip, and two of the jar rims have orifice diameters of $16 \mathrm{~cm}$ and $27 \mathrm{~cm}$. Rim form $\mathrm{D}(\mathrm{n}=4$, one sherd each from Units $6,7,8$, and 13 ) is everted with a flat lip, and rim thickness ranges between $5.5-7.0 \mathrm{~mm}$. One jar has a $17 \mathrm{~cm}$ orifice diameter. The one bowl rim in Rim form $\mathrm{E}$ (Unit 12) is direct with a rounded 


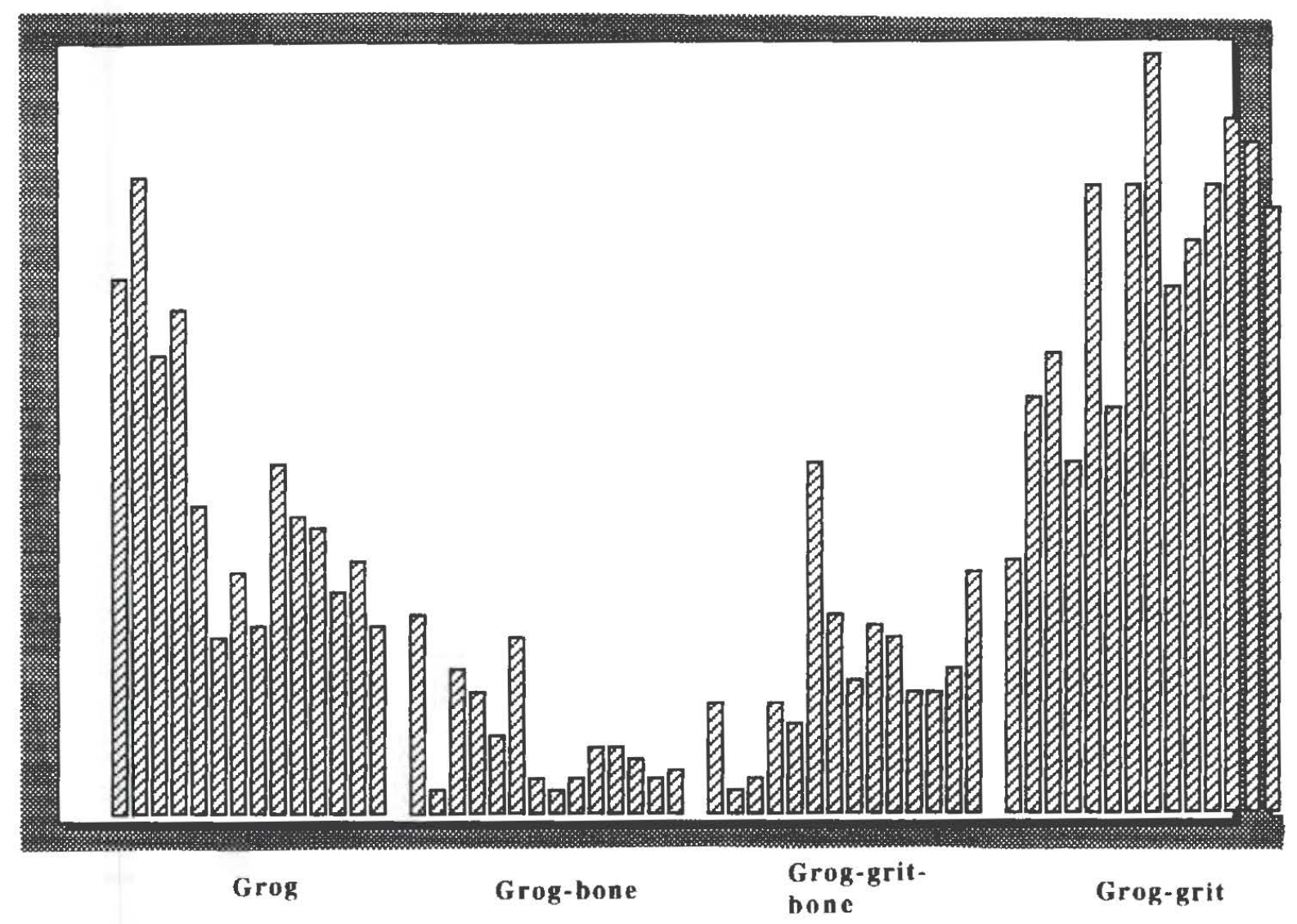

Figure 3. Proportions of Temper Classes in Sherds by Unit: Grog, Grog-bone, Grog-grit-bone, and Groggrit. Note columns for each Temper Class begin with Unit 1 on the left, and end with Unit 15 on the right. 
lip, and the interior of the rim has been beveled. Rim form $F(n=2$, Units $8 X$ and 15$)$ is direct with a rounded lip, but the rim has been beveled on the exterior of the bowl. 'These vessels have thick walls, ranging from 8.5-9.0 mm. Rim Form $\mathrm{G}(\mathrm{n}=5$, from Units 8, 12 , and 14) is direct with a flat lip, and they appear to be from bowls with thin walls (4.8-7.0 $\mathrm{mm})$. One bowl with a form $\mathrm{G}$ rim has a $29 \mathrm{~cm}$ orifice diameter. Rim form $\mathrm{H}$ is the most common form, with 11 examples from Units $2,6,8,11,13,14$, and 15 . It is direct or standing with a rounded lip, and includes bowls and one bottle rim (from Unit 13); rim wall thickness ranges from 5.2-6.5 mm. One bowl has a $22 \mathrm{~cm}$ orifice diameter.

The distribution of rim forms in the four site areas indicates that there is an impressive diversity of rim and lip forms, and in vessel forms, in the northwestern part of the site (Area IV) (Table 3). The frequency of Rim Form D in three different areas of the site, and the fact that brushed pottery is more abundant in two of the three areas (i.e., Unit $3 / 7$ and Unit 2, 5, and 6), suggests that this may be a slightly later rim and vessel form than the other seven rim forms at Gray's Pasture.

Table 3. Rim Forms

\section{Rim Forms}

\begin{tabular}{|c|c|c|c|c|c|c|c|c|}
\hline Areas & $\mathbf{A}$ & $\mathbf{B}$ & C & $\mathbf{D}$ & $\mathbf{E}$ & F & G & $\mathbf{H}$ \\
\hline \multicolumn{9}{|l|}{ Unit 1} \\
\hline Unit $3 / 7$ & & & & 1 & & & & \\
\hline Unit $2,5,6$ & & & & 1 & & & & 2 \\
\hline $\begin{array}{l}\text { Unit } 8,8 \mathrm{X} \text {, } \\
10-16\end{array}$ & 1 & 2 & 4 & 2 & 1 & 2 & 5 & 9 \\
\hline Totals & 1 & 2 & 4 & 4 & 1 & 2 & 5 & 11 \\
\hline
\end{tabular}

\section{DECORATED RIM AND BODY SHERDS}

The decorated rim and body sherds are sorted in terms of the method of decoration, such as incising, punctating, engraving, incising-punctating, and brushing, and the decorative element or pattern. These include specific recognizable kinds of decoration on the vessel rim and/or body, such as cross-hatched incised lines or an engraved ladder, if the sherd was sufficiently large to determine the element or pattern; when the element or pattern could not be determined, general terms have been employed to describe the decorated sherd (i.e., single incised line, unidentified engraved element, etc.). Where possible, rim and body patterns defined by Schambach et al. (n.d.) are identified in the decorated rim and body sherds from the Gray's Pasture site. Because many of the decorated sherds are rather small ( $1-2 \mathrm{~cm}$ in length and width), this was not possible in most cases.

Not including the 11 plain red-slipped sherds (see above), there are 551 decorated rim and body sherds in the Gray's Pasture collection. About $82 \%$ of the decorated sherds are from Area IV $(n=451)$, followed by Area III $(n=61)$, Area I $(n=19)$, and Area II $(n=15)$. The four site areas (Figure 4), and the excavation units within each of the areas (Figure 5), are different with respect to the relative frequency of the different methods of vessel decoration. Brushed and punctated sherds are most common in Areas I, II, and III 


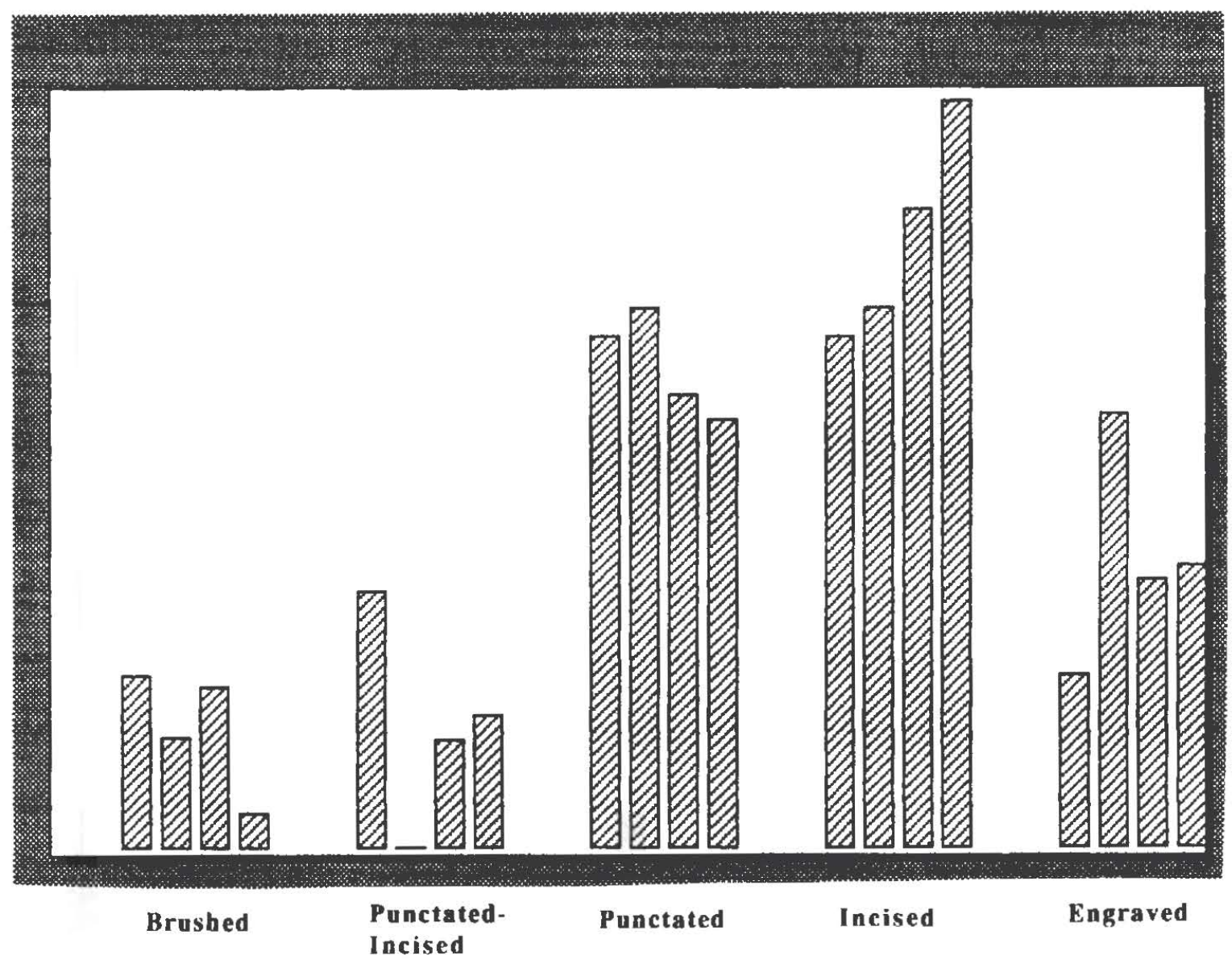

Figure 4. Proportions of Decorated Sherds by Area, including Brushed, Punctated-Incised, Punctated, Incised, and Engraved. Note columns for each Area begin with Area I on the left, and end with Area IV on the right. 


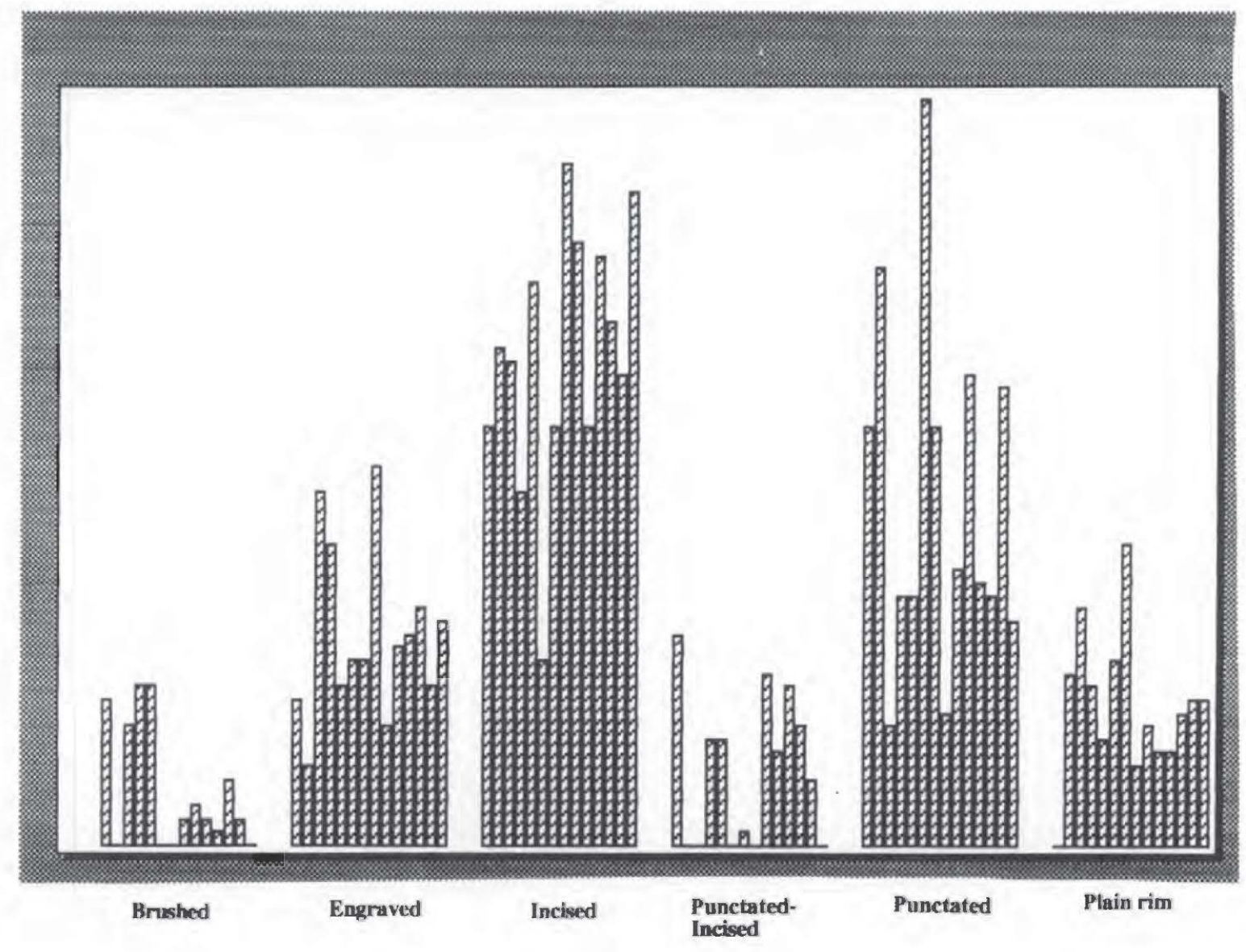

Figure 5. Proportions of Decorated Sherds and Rim Sherds by Unit: Brushed, Engraved, Incised, PunctatedIncised, Punctated, and Plain Rim. Note columns for each Decorative Class begin with Unit 1 on the left, and end with Unit 15 on the right. 
(see Figure 4); engraved sherds are more abundant in Area II (particularly in Unit 3); incised sherds are the most popular in Area IV; and incised-punctated sherds are relatively common in Areas I, III, and IV, but are absent in Area II (see Figures 4 and 5). More specific differences in decorative elements, as discussed in more detail below, suggest that parallel brushed body sherds are more common than expected in Units 1, 5, and 6 in Areas I and III, as are curvilinear, nested triangle, and cross-hatched incised elements in Units 8, $8 \mathrm{X}, 12$, and 14 in Area IV. Most of the more distinctive engraved decorative elements (see Table 2) are found in Area IV.

As with the plain body and base sherds, the decorated sherds are primarily tempered with grog and grit $(52.3 \%)$, followed by grog $(34.2 \%)$, grog-grit-bone $(7.2 \%)$, and grog-bone $(6.3 \%)$. Proportionally, more of the decorated sherds are tempered with grog than is the case among the plain body and base sherds $(27.2 \%)$, and this is particularly so for the engraved $(34.6 \%)$ and punctated $(41.7 \%)$ sherds. Grog may have been preferred for the engraved and punctated sherds--especially finely crushed grog-because it allowed the vessel to be fired longer in a reducing environment and created a harder and more durable vessel.

\section{Incised Sherds}

The incised rim and body sherds comprise approximately $40-46 \%$ of the decorated sherds in Areas III and IV (see Figures 4 and 5). By contrast, only $31-33 \%$ of the decorated sherds in Areas I and II have incised decorations.

The most common incised rim pattern has widely-spaced diagonal lines $(n=12$, $83 \%$ from Area IV), probably the Albertus pattern (Figure 6b). These are from large jars or deep bowls with $18-26 \mathrm{~cm}$ orifice diameters. There are four body sherds, one from Area III and three from Area IV, with a widely-spaced diagonal incised decoration. Another rim from Area IV has narrowly-spaced diagonal lines.

Two rims from Area IV have cross-hatched or criss-cross incised lines on the rim, an Anthony 2 pattern from Unit 10 (Figure 6h) and an Anthony 3 pattern from Feature 2. Both are direct rims with rounded lips. Another cross-hatched incised rim is in Area III (Figure 6f). Cross-hatched incised body sherds (Adelphi body pattern?) include 12 with widely-spaced cross-hatching ( $92 \%$ from Area IV, including one body sherd from Feature 1 fill) and another 12 with closely-spaced cross-hatched incised lines (also $92 \%$ from Area IV).

A distinctive grog-tempered jar with an Andres 16 rim pattern is represented by three rim sherds in Area IV. The vessel has a triple panel of pitched right and pitched left diagonal incised lines divided by horizontal incised lines, and the lip is notched. The rim is everted with a rounded lip, and has an estimated orifice diameter between 16-24 cm (Figure $6 c)$.

One Area I rim has an incised nested triangle decorative element (Afton I pattern). The rim is direct with a rounded lip that has been folded to the exterior. Another 20 body sherds have incised nested triangles, probably from the lower part of Afton 1 rims (Figure $6 \mathrm{a}, \mathrm{d}, \mathrm{g}$ ), but possibly also including some Alma 3 body patterns (nested triangles in vertical lines on vessel bodies) or Alpha body patterns (i.e., narrow vertical patterns of diagonal incised lines on vessel bodies). 


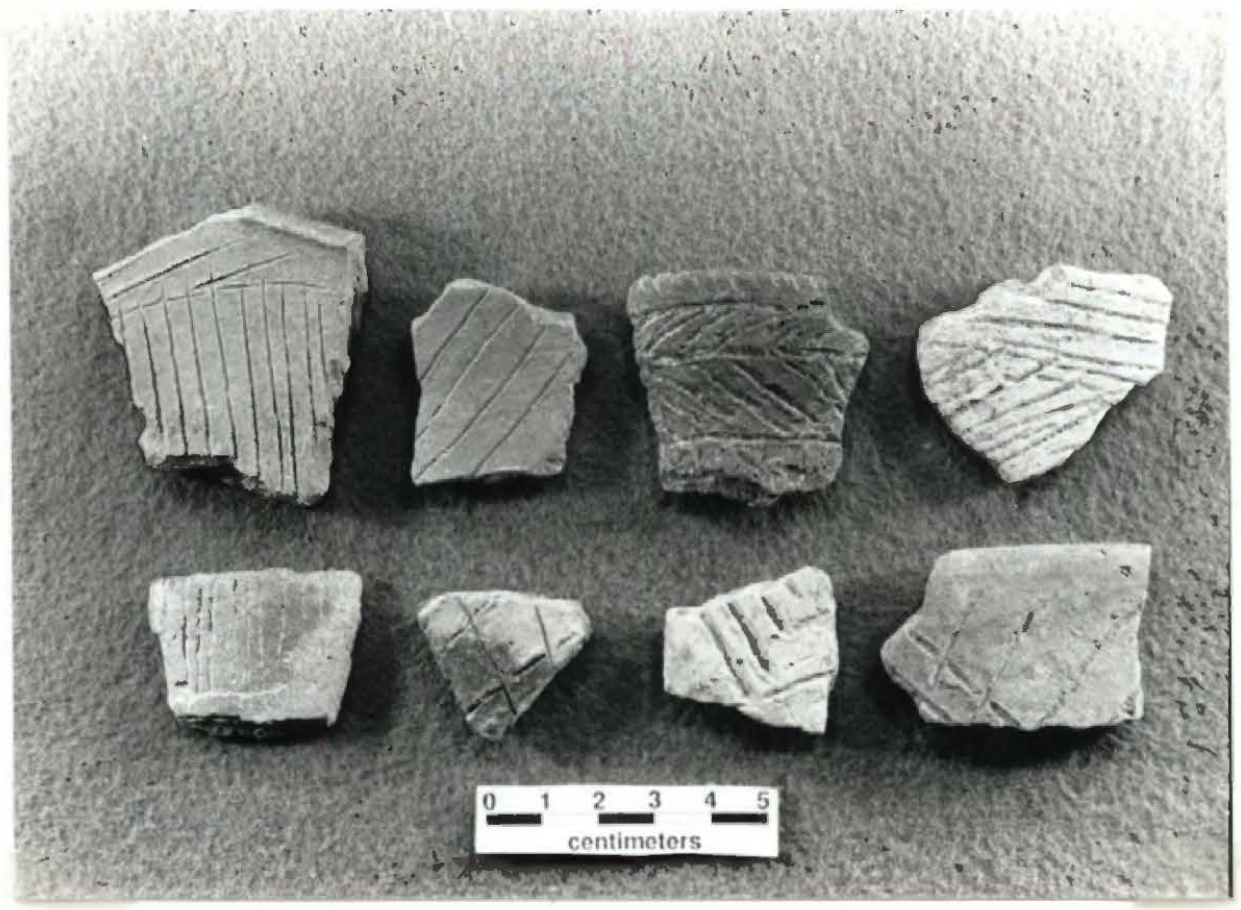

Figure 6. Incised Rim and Body Sherds from the Gray's Pasture site.

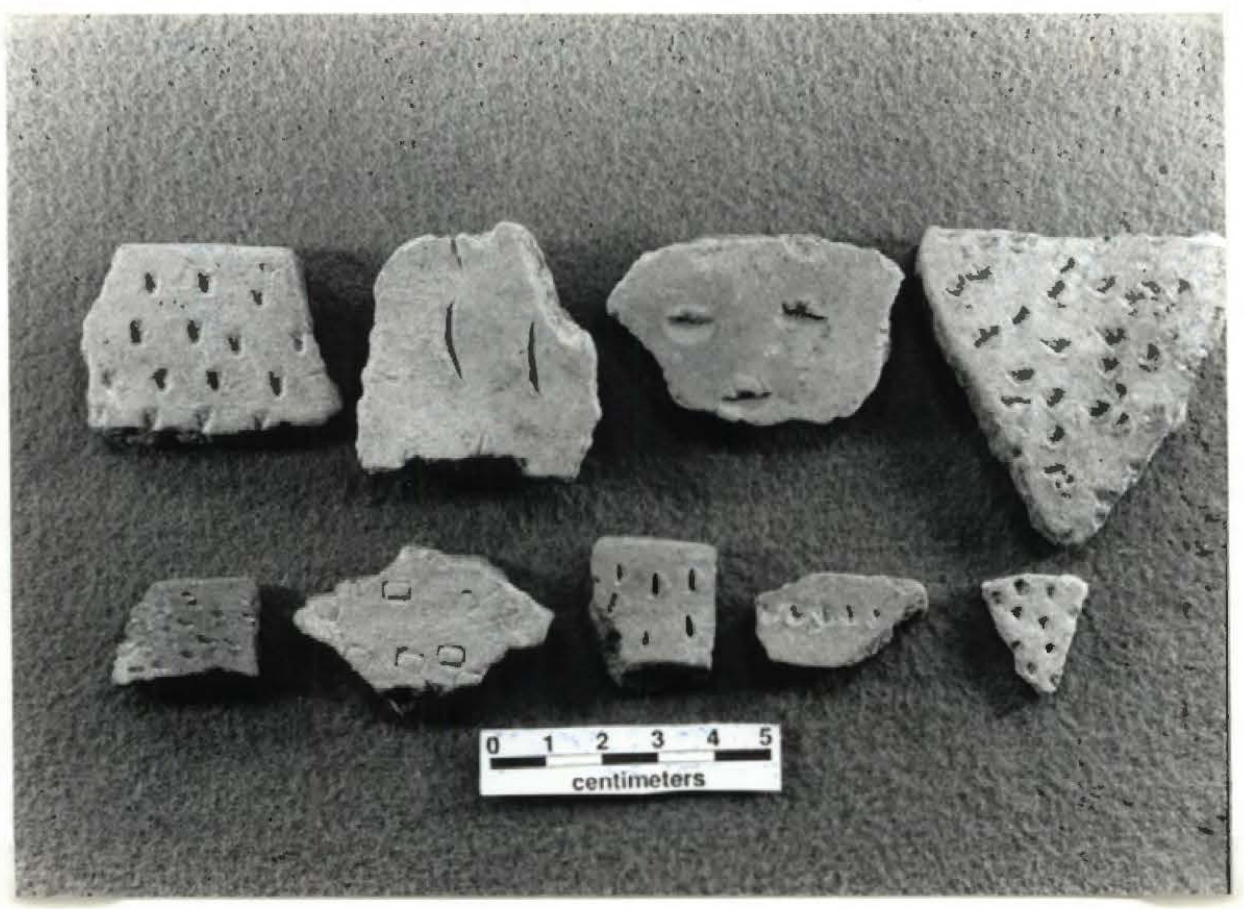

Figure 7. Punctated Rim and Body Sherds from the Gray's Pasture site. 
Three small rims in Area IV have a horizontal incised line on them, but the sherds are too small to recognize the larger decorative element or pattern. All three rims are direct with rounded lips, and the lip has been folded to the exterior.

Nine body sherds have closely-spaced broad vertical incised lines (Abraham body pattern), seven from Area IV (Figure 6e) and two from Area III. An Alpha I body pattern-simple herringbones in narrow incised panels, with one line between the panels--is present on a single sherd from Area IV.

Many incised body sherds have incomplete decorative elements or patterns. This includes 76 sherds with a single incised line ( $83 \%$ from Area IV), 48 sherds with at least 2 . 3 broad and parallel incised lines ( $90 \%$ from Area IV), and 19 sherds with at least $4-9$ narrowly-spaced parallel incised lines (79\% from Area IV).

\section{Punctated Sherds}

On rims, the most common decorative element or pattern is rows (up to four rows) of large circular tool punctations. The five examples from Gray's Pasture are from Area I $(\mathrm{n}=1)$, Area III $(\mathrm{n}=2)$, and Area IV (Figure 7a, g; $\mathrm{n}=2)$. Another well-represented decorative element is vertically placed fingernail punctated rows (Concord 1 pattern). These three rims are from large jars (24-26 cm orifice diameter), and are found only in Area IV.

Two other punctated rim sherds have small diagonally-placed and broad tool punctations on the rim (Chattanooga, Concord 6, or Concord 8 rim patterns). These are from Area IV. Narrow diagonal tool punctated rims (Concord?) are represented by single specimens in Area III and IV. Another but small rim has small circular punctations as the decorative element, probably placed diagonally across the rim. It is from Area IV. There is a dentate tool punctated rim sherd, with at least one row of punctations, from Area IV.

Body sherds with punctated decorative elements are present in each of the four areas at the Gray's Pasture site, but punctated sherds are proportionally more abundant in Areas 1 and II (see Figure 4), but units in Areas III and IV also have a large number of punctated body sherds (see Figure 5). Large circular tool punctations (Figure 7c) are the most common decorative element ( $\mathrm{n}=44$, including 39 sherds in Area IV), followed by large and widely-spaced fingernail punctations (Figure $7 \mathrm{~b} ; \mathrm{n}=39$, including 34 sherds in Area IV) as well as small (Figure 7e) and closely-spaced fingernail punctates $(\mathrm{n}=14,79 \%$ from Area IV). Other tool punctated sherds have triangular punctated marks $(n=1$, from Area I) or large half-moon-shaped stab and drag tool marks (Figure 7d; $n=21,16$ of which are from Area IV). The remainder of the punctated body sherds appear to have been primarily made using a small cane or stick (Figure $7 \mathrm{i} ; \mathrm{n}=12$, with nine from Area IV), although two other punctated body sherds have either a single row of circular punctations (Figure 7h, Unit 11 in Area IV) or large reed punctations (Figure 7f, Unit 2 in Area III).

\section{Engraved Sherds}

Engraved rim and body sherds are common across the four areas at the Gray's Pasture site, particularly in Units 3, 5, and 8X (see Figure 5). Proportionally, these finewares are more abundant in Area II, however, as are punctated sherds (see Figure 4).

There are 25 engraved rim sherds, and about $44 \%$ have horizontal engraved lines on the rim; the vast majority of these sherds are from Area IV, with one rim in Area II (Figure 8b, $\mathrm{c}$ and Figure 9b). Three body sherds from Area III and IV also appear to have 


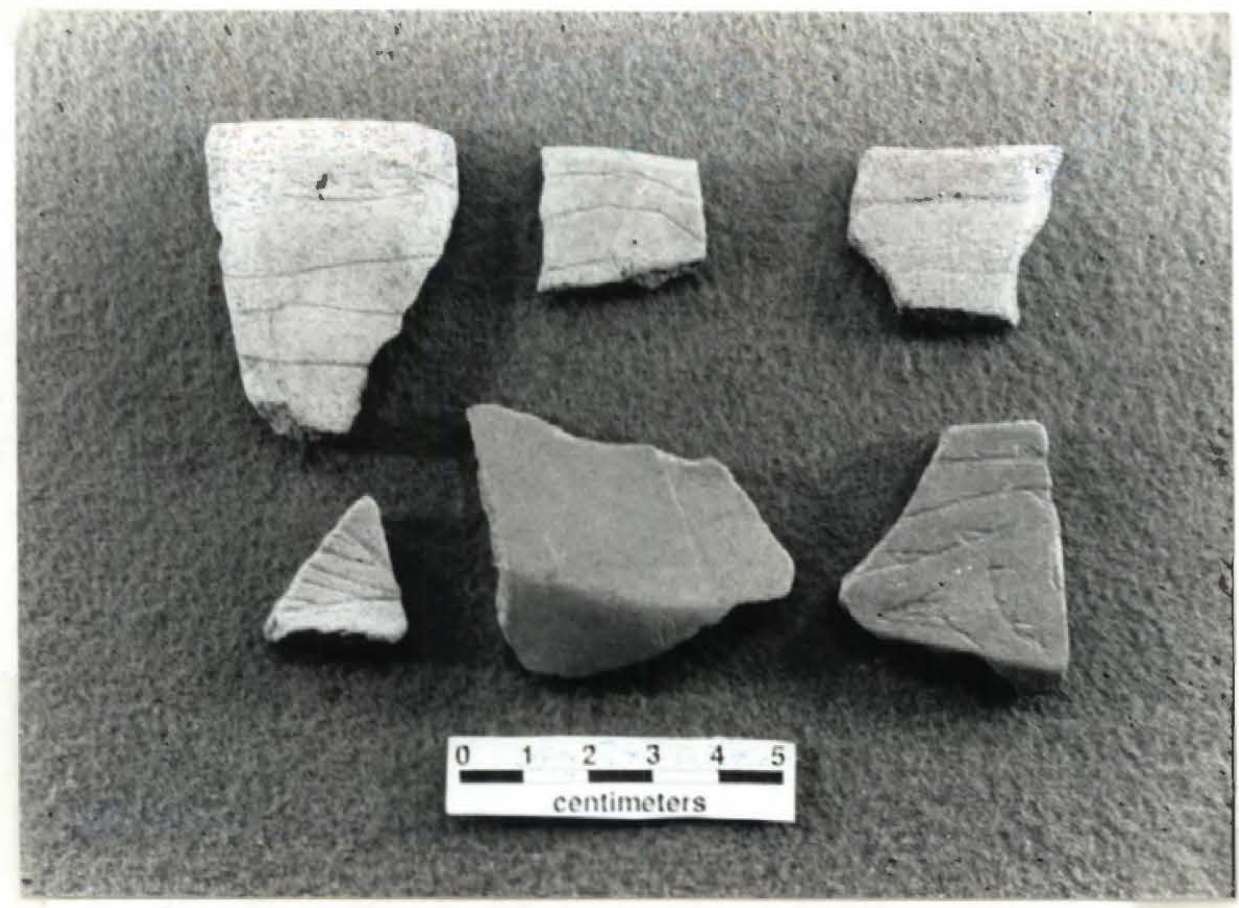

Figure 8. Engraved sherds from the Gray's Pasture site.

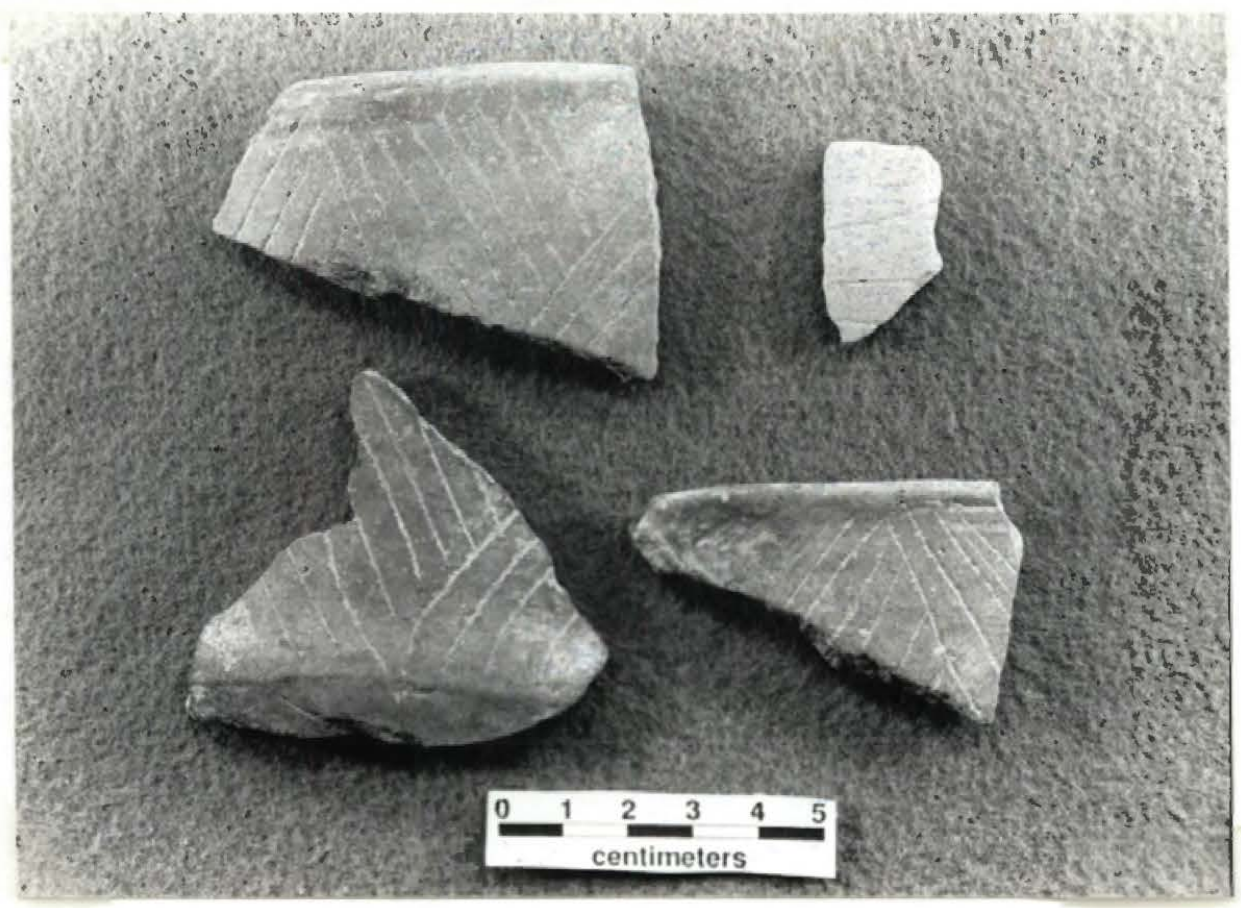

Figure 9. Diagonal, Horizontal, and Opposed Diagonal Engraved Rim Sherds. 
horizontally engraved lines. The rims are direct, with rounded $(n=6)$ or flat $(n=4)$ lips. One horizontally engraved rim from Area Iv (Unit 12) also has lip notching. Another rim in Area IV also has a red slip on the exterior surface. Another $33 \%$ are rims from carinated bowls (19-22 cm orifice diameters), with an opposed diagonal engraved decorative element (Figure 9c-d). The rims are direct, with rounded $(n=2)$, flat $(n=2)$, and folded lips $(n=4)$. Except for one rim found on the surface, the others with this decorative element are from Area IV. Three other rims from Area IV, and four body sherds (from Areas III and IV), have broad engraved diagonals (see Figures 8d-e and 9a); one of the Area III body sherds has an exterior red slip.

Two Area IV rim sherds have horizontal engraved ladders placed below the lip of carinated bowls. They have direct rims with rounded lips.

A single rim from a medium-sized (16 cm orifice diameter) bowl or carinated bowl in Area III has a horizontal and curvilinear engraved decorative element. Two bottle neck sherds from Area IV have single or multiple engraved lines encircling the neck, and are probably from Holly Fine Engraved or Hickory Engraved bottles (see Figure 8a). Another bottle sherd from Area IV has a number of engraved concentric semi-circles on the vessel body.

Engraved decorations on the bodies are diverse. This includes engraved diagonals or filler zones ( $n=5$, Area IV); excised/engraved triangles ( $n=3$, Area IV); curvilinear diagonal filler zones ( $n=1$, Area IV); horizontal lines (one sherd in Area IV); closely-spaced cross-hatching (one sherd in the Burial 2 fill); irregular cross-hatching ( $n=1$, Area IV); rectilinear and curvilinear ( $n=1$, Area IV); and horizontal and rectilinear $(n=1$, Area IV). There is a distinctive body sherd from a carinated bowl in Area IV that has an engraved scroll with excised triangles (see Figure 8f), and one sherd in Area III has a possible Holly Fine Engraved or Spiro Engraved motif with a circular and intersecting vertical panel decorative element. Sherds with unidentifiable decorative elements include 33 with a single straight line and nine with a single curvilinear engraved line. More than $93 \%$ of these sherds are from Area IV.

\section{Incised-Punctated Sherds}

Incised-punctated sherds are present in Areas I, III, and IV, and they are proportionally most common in Area I and III (see Figure 4). There are six Pennington Punctated-Incised rim sherds, all from Area IV (Figure 10b-c). Four have altemating triangular incised zones at the rim that are filled with circular punctations (see Suhm and Jelks 1962:Plate 61f), and the rims are direct with rounded lips. One rim from Unit 10 (level 3 ) has a suspension hole drilled below the lip. A fifth Pennington Punctated-Incised rim has alternating sets of diagonally incised zones filled with small circular punctations (see Suhm and Jelks 1962:Plate 61 b), and the sixth also has the alternating sets of diagonal incised zones (Figure 11b), but the zones are filled with rows of small triangular-shaped tool punctations (see Suhm and Jelks 1962:Plate 61I). Both rims are direct with rounded lips.

An incised-punctated rim sherd from Area III has a rim peak, with a horizontally incised line around the rim. The rim peak itself is filled with a series of short verticallyplaced punctations; the rim is everted, with a rounded lip. In Area IV, a rim from Unit 8 has short vertically-placed punctations that have been placed between the lip and a horizontal incised line part way down the rim of the bowl. 


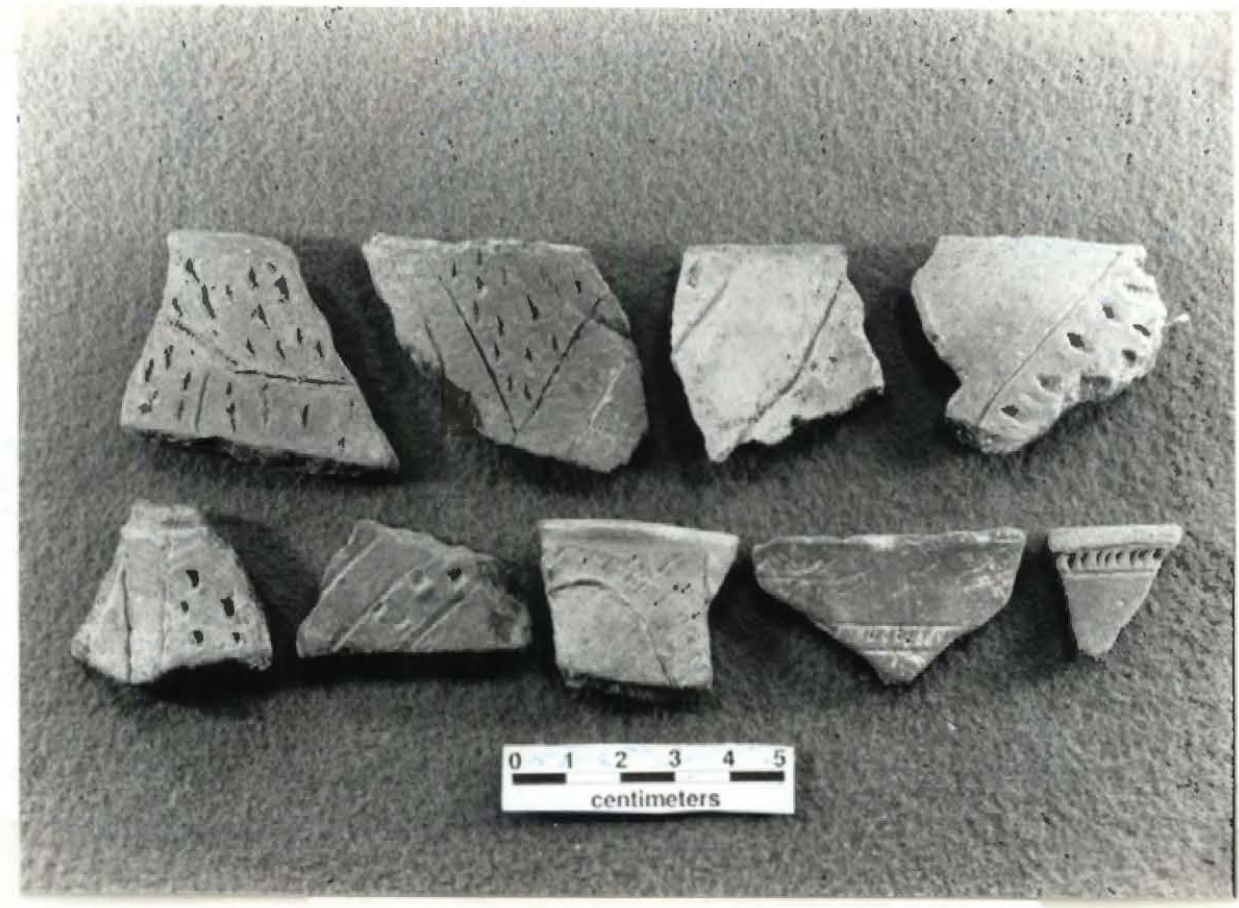

Figure 10. Incised-Punctated Rim and Body Sherds.

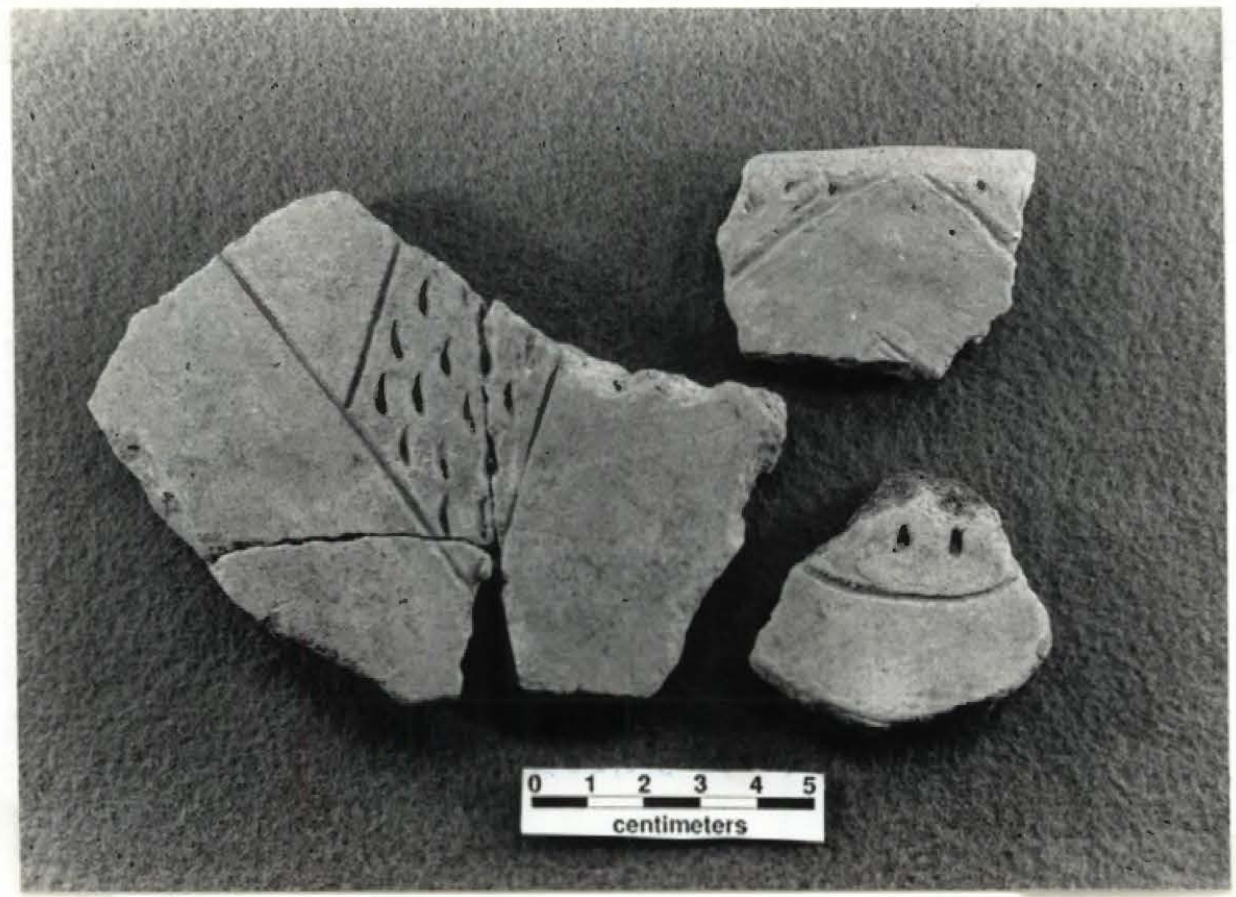

Figure 11. Probable Pennington Punctated-Incised and Crockett Curvilinear Incised sherds. 
One rim sherd and one body sherd from Area IV have horizontal incised lines with a row of tool punctations adjacent to the incising or within the horizontal incised lines (Case 4 pattern). The latter rim sherd is direct with a rounded lip that has been folded to the exterior of the vessel (see Figure 10i), and it is tempered with grit.

One large Pennington Punctated-Incised body sherd from Area IV (Unit 12, level 1) has a diagonally incised panel filled with large vertically-placed circular punctations; the panel intersects a single broad incised line that probably encircles the vessel (see Figure 11a). Five body sherds, one from the surface, one from Area I, one from Area II (see Figure 10e), and two from Area IV have sets of nested triangles divided by opposed diagonal incised lines. The incised triangles are filled with tool or stick punctations.

Two incised-punctated rim sherds, both from Area IV, have curvilinear-rectilinear or curvilinear-circular incised zones filled with tool punctations, one a Cambridge 4 pattern (see Figure 10a) and the other a Chatham 1 pattern (see Figure $10 \mathrm{~g}$ and Schambach et al. n.d.). Both rims have rounded lips, and the Cambridge 4 rim is slightly everted while the Chatham 1 rim is direct.

Many of the smaller incised-punctated sherds ( $n=22,77 \%$ from Area IV) have only a single incised line with an adjacent zones of fingernail or tool punctations, but the larger decorative element or pattern is undetermined. Eleven incised-punctated sherds, all from Area IV, including from the fill of Burial 2, have curvilinear incised lines with circular tool punctates within an incised circle (see Figure 10h and Figure 11c), and these are probably from Crockett Curvilinear Incised bowls. They are either Casper 1, 2, or 7 body patterns in Schambach et al. (n.d.). Another probable Crockett Curvilinear Incised body sherd (from Area III) has intersecting horizontal and vertical incised panels filled with small circular punctations (see Suhm and Jelks 1962:Plate 17s). One sherd from Area IV has a diagonal incised panel on it that intersects a narrow incised zone filled with a single row of small punctations (see Figure 10f), and two other sherds (one each from Areas III and IV) have a parallel set of incised lines, with a row of small punctations placed between two of the parallel incised lines. Finally, one body sherd from Area I has an incised panel filled with randomly placed and small circular punctations.

\section{Brushed Sherds}

Brushed sherds are not abundant at the Gray's Pasture site, accounting for $3.7 \%$ of the decorated sherds. Although the sample of decorated sherds is small outside of Area IV, the brushed sherds are relatively more abundant in Areas I, II and III compared to Area IV (see Figure 4 and Table 2), which suggests that the Area IV occupation is somewhat older than the Caddoan components in the other three site areas.

Both brushed rim sherds are from Area IV. One, a Davidson 1 pattern (see Schambach et al. n.d.) has vertical brushing on a jar rim with a direct rim and flat lip, and the other has diagonal brushing marks (Dawson 5 pattern). The decorated body sherds are dominated by parallel brush marks with no apparent design (Danbury body pattern), although there is one sherd from Area IV with rectilinear brushing (Dartmouth body pattern) on the vessel body. Two other body sherds from Area IV have parallel brush marks with wide diagonal incised lines placed over the brushing. There are also two sherds--one from the surface and the other from Area IIl--with parallel brushing marks with 1-2 rows of tool punctations placed through the brushing. Although this decorative clement is rare at Gray's Pasture, by ca. A.D. 1350-1450, brushed-punctated vessels are abundant in many middle Sabine River basin Caddoan sites, including Oak Hill Village (Perttula 1999b), 41RK240 (Perttula 2000), and Bryan Hardy (Walters and Haskins 
2000). At the Bryan Hardy site, for example, brushed-punctated sherds comprise about $16 \%$ of the decorated sherds (Walters and Haskins 2000:Table 2).

\section{WHOLE VESSELS FROM BURIALS 1 AND 2}

The two burials in Area IV were in pits oriented northwest-southeast (Figure 12), primarily in Units 8 and 10 . Each burial has two whole vessels. The vessels were not available for study as part of this paper, but Keller (1992a:27) did provide limited descriptions of them, and photographs of two of the vessels are available.

Both vessels in Burial 1 are decorated, and both are bowls. Vessel \#I (Figure 13) stood about $6 \mathrm{~cm}$ in height, with an $11.5 \mathrm{~cm}$ orifice diameter. The rim was direct with a rounded and folded lip. The decoration consists of horizontal and vertically incised zones on the rim that are filled with rounded (cane?) punctations. Vessel \#2 was described by Keller (1992a:27) as a "smaller Canton Incised bowl," but the actual decorative element is not mentioned.

Keller (1992a:27) described the Burial 2 vessels as a plain wide-mouthed jar (Vessel \#3, Figure 14) and Vessel \#4 as a shallow and plain carinated bowl. The jar stood about $8 \mathrm{~cm}$ in height, with a ca. $13 \mathrm{~cm}$ orifice diameter. The rim was slightly everted, with a rounded lip.

\section{CERAMIC CLAY PIPES}

Eight ceramic clay pipe sherds from long-stemmed Red River style pipes are included in the ceramic assemblage from the Gray's Pasture site, including six stems, one bowl rim, and one distal stem projection. Seven of the long-stemmed pipe sherds are from Area IV, and appear to be from Early Caddoan Miller's Crossing and/or Graves Chapel varieties (see Hoffman 1967), and there is a single bowl sherd from Area I.

The one bowl sherd (Figure 15e) from Area I has been tempered with grog and has a smoothed exterior; it was also fired in a reducing environment. It has a flat lip, but the sherd is too small to estimate the bowl diameter or height. The distal stem projection is from Unit 15 in Area IV (see Figure 15c). The stem projection extends beyond the bowl, at the opposite end of the pipe from the mouthpiece. The pipe is tempered with grog and bone, and the exterior has been smoothed. The stem hole is $5.4 \mathrm{~mm}$ and the stem diameter is $12.2 \mathrm{~mm}$.

The six pipe stem sherds include three that end at the mouthpiece (see Figure 15b, $\mathrm{d}, \mathrm{g}$ ) and two stems that are immediately below the pipe bowl (see Figure 15a, f), as well as another sherd from an undetermined part of the stem (see Figure 15h). Three stems are tempered with grog and hematite, two have grog temper, and the sixth stem has bone temper; 33\% have exterior smoothed surfaces. All are from pipes that were reduced during firing. Including the distal stem projection discussed above, the mean stem diameter of the Gray's Pasture pipes is $11.52 \mathrm{~mm}$, and the mean stem hole diameter is $4.92 \mathrm{~mm}$. These pipes are about the same size as the ca. A.D. 1150-1400 long-stemmed pipes from the Oak Hill Village, except the mean stem hole diameters are smaller at Gray's Pasture than at Oak Hill Village: $4.92 \mathrm{~mm}$ versus 5.24-6.50 mm (Rogers 1999). The earlier pipes at Oak Hill, in pre-A.D. 1250 contexts, are comparable in mean stem diameter (9.61-10.76 mm) and mean stem hole diameter $(5.24-5.56 \mathrm{~mm})$. 


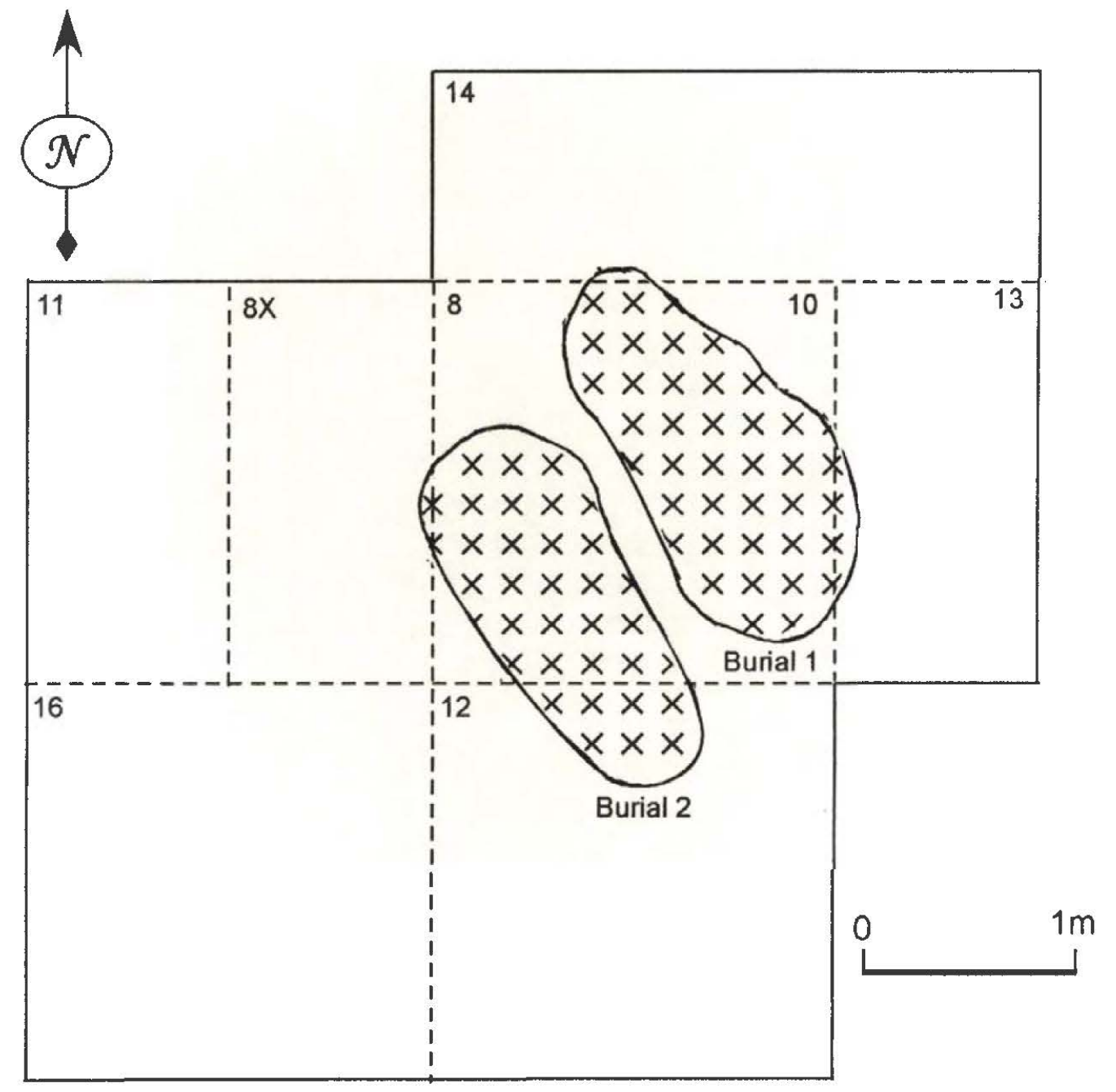

Figure 12. Burials 1 and 2 in Area IV at the Gray's Pasture site. 


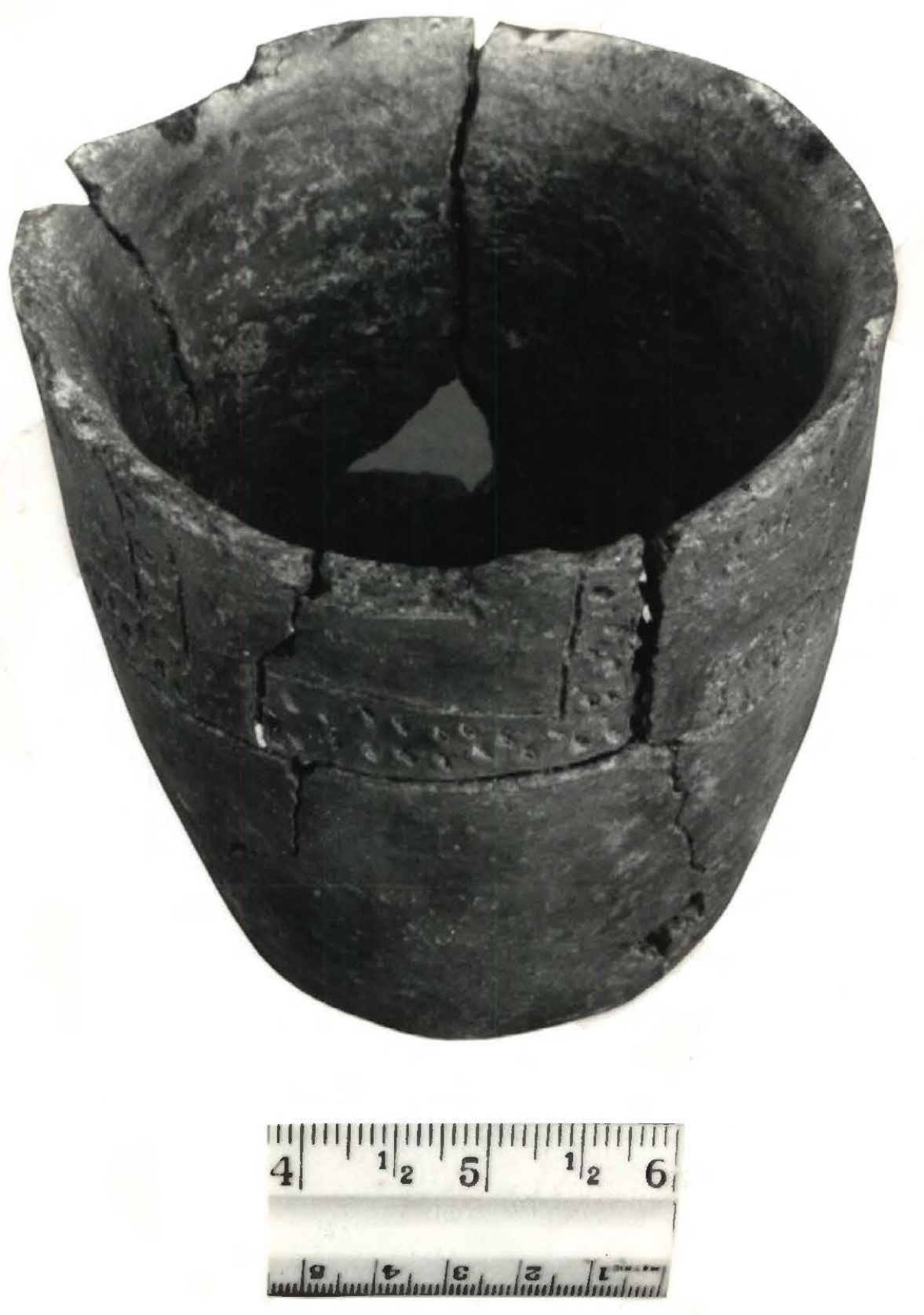

Figure 13. Vessel \#1, Burial 1. 

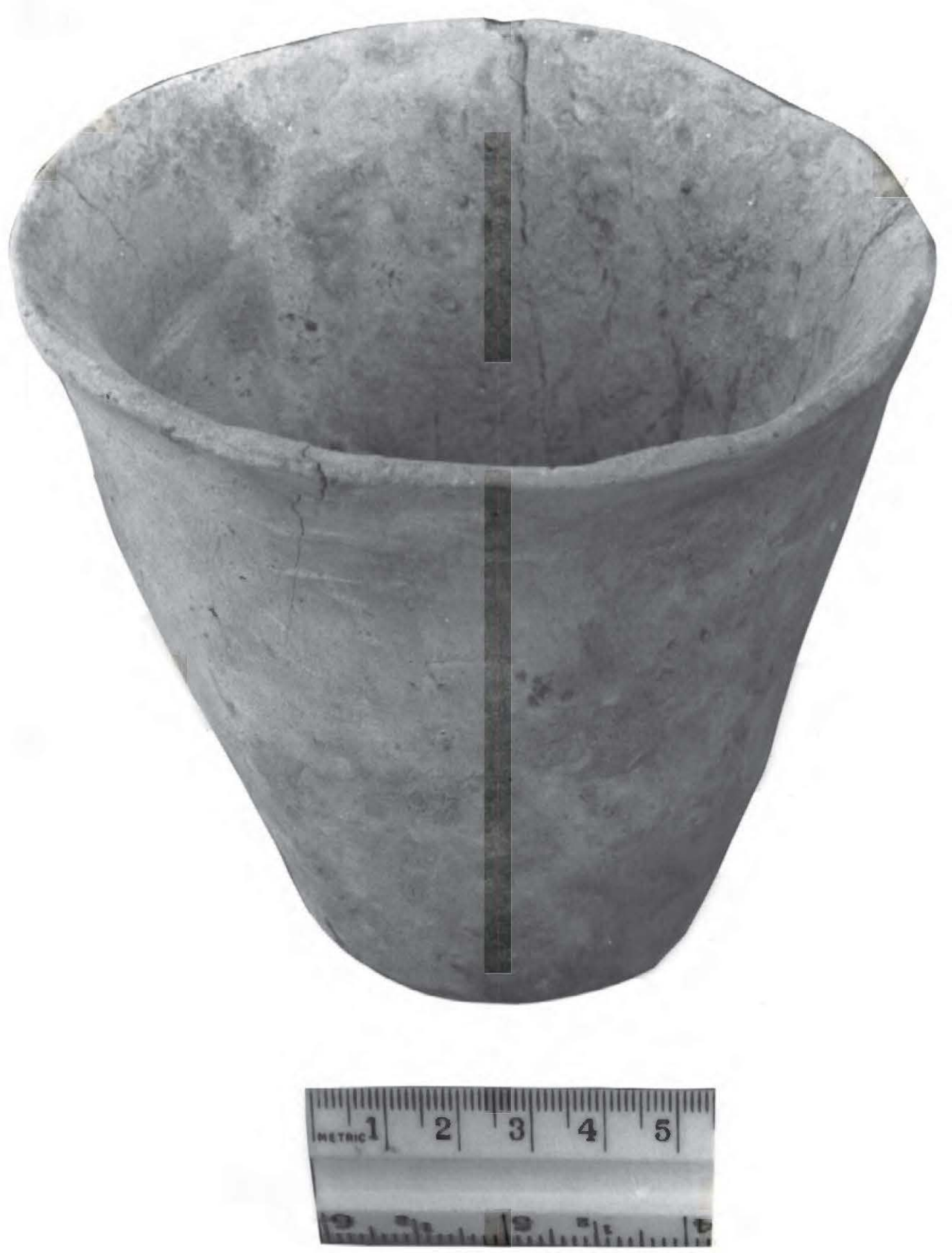

Figure 14. Vessel \#3, Burial 1. 

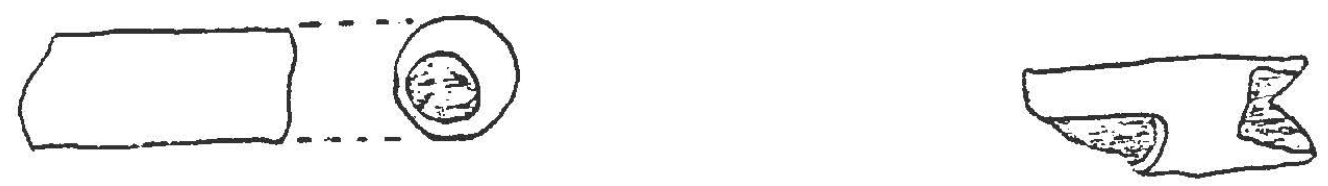

Unit 8, Level 2

Onit 14, Level 4
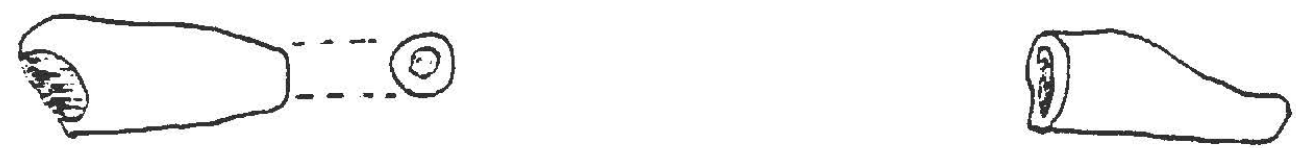

onit 15, Level 1

Onit 11, Level 4
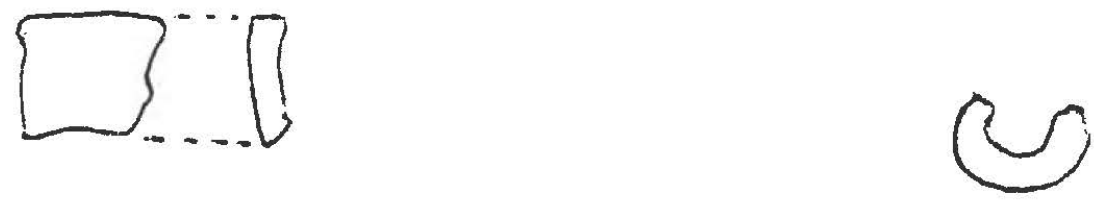

Onit 1, Level 7

Onit 13, Level 2
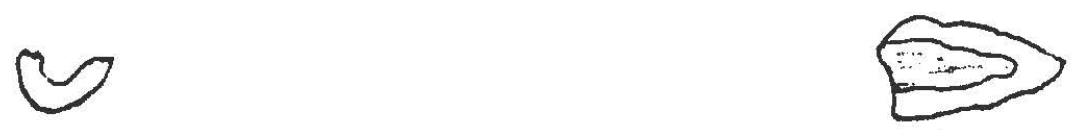

Onit 15, Level 2

Onit 15, Level 2

Figure 15. Long-stemmed clay pipe sherds from the Gray's Pasture site. All sherds are shown at actual size. 


\section{RADIOCARBON DATE FROM THE GRAY'S PASTURE SITE (41HS524), Timothy K. Pertula, Mike Turner, and Bo Nelson}

As part of the analysis of the archeological materials from the 1992 Northeast Texas Archeological Society (NETAS) field school held at the Gray's Pasture site (41HS524), it was important to attempt to more definitively establish the chronological context of the Caddoan occupation there. Keller (1992a) had estimated that the Caddoan occupation of the site took place around A.D. $1100-1250$ based on an initial examination of the ceramic sherds and vessels found during the field school. Accordingly, a radiocarbon sample of charred hickory nutshells from the Gray's Pasture site was sent to Beta Analytic, Inc. from Feature 2 (50-70 $\mathrm{cm}$ below surface in Unit 10$)$, one of the two Caddoan burials uncovered during the work (Keller 1992).

According to Keller (1992a:27), Feature 2 was:

a shallow basin with a more or less oval-shaped outline; it contained two associated vessels. The grave outline measures approximately $180 \times 80 \mathrm{~cm}$ and orientation is....southeast to northwest with the skull oriented toward the southeast. The burial was extended and supine...a subadult of less than 15 years of age.

Preservation of the human remains was poor, and only small flecks of charred materials were present in the grave fill. The charred hickory nutshells we selected for radiocarbon dating occurred at the same level as the burial itself, near the floor of the grave.

Because only a small amount of charred nutshells ( $<0.1$ grams) were present in the Feature 2 sample, the radiocarbon sample was analyzed by Beta Analytic, Inc. at an accelerator mass spectrometer (AMS) at the Lawrence-Livermore National Laboratory in Berkeley, California. The measured radiocarbon age of the charred nutshells is $2570 \pm 50$ years before present (B.P.) (Beta-92922). After applying the C13/C12 ratio $(-29.1 \mathrm{o} / \mathrm{oo})$ carbon corrections to the measured age, the conventional and uncalibrated radiocarbon age of the AMS sample is $2510 \pm 50$ B.P., or 560 B.C.

Using the Pretoria Calibration Procedure program (Vogel et al. 1993), therc is a $68 \%$ probability (one sigma) that the calibrated date from the charred nutshells in Feature 2 falls between $785-525 \mathrm{BC}$. At two sigma (or $95 \%$ probability), the calibrated date for the charred nutshells is $800-415 \mathrm{BC}$.

What do we make of this radiocarbon date? Clearly, the date does not represent an accurate age estimate for the Caddoan burial, since it has been well established with several hundred radiocarbon dates, and changes in ceramic styles, that the Caddoan occupation of Northeast Texas began about A.D. 800. That does not mean that it should be assumed that the radiocarbon date is not accurate, however, since it is always important in evaluating the accuracy of a date to establish a clear link between the material being dated (i.e., the nutshell), its context, and the target event (i.e., the age of the Feature 2 interment) of archeological interest.

We had assumed that the nutshell was associated with the Feature 2 interment because it was found in association with the skeletal remains and the ceramic vessels, but in hindsight we had no archeological information available that specifically linked the burial fill and its contents with the age of the interment itself. It seems likely, therefore, that the nutshell we selected for dating from the fill of the grave had been deposited at the Gray's Pasture site during the substantial Late Archaic occupation there (based on the number of dart points found at the site during the NETAS field school and in local collections [Keller 
1992:26] and other dates on Late Archaic components in Northeast Texas). When the burial was excavated, the nutshell from an earlier occupational episode in the area simply became incorporated into the fill of the grave.

Based on the results of the radiocarbon datc from the Gray's Pasture site, we would recommend in the future that a more realistic approach to dating Caddoan features like Feature 2 would be to collect samples of carbonized organic materials preserved on the walls of ceramic vessels or pipes placed in the graves (see Perttula et al. 1998). There is an obvious link there between the occupational episode of concern and the organic materials to be submitted for radiocarbon dating. Unfortunately, no carbonized organic materials were preserved on any of the vessels placed with the two burials at the Gray's Pasture site.

\section{MIDDLE SABINE RIVER CADDOAN CERAMICS AND COMPARISONS WITH THE GRAY'S PASTURE SITE}

\section{South Hallsville Ceramic Sites}

Extensive archeological survey and test excavations in the South Hallsville mine area has identified a number of archeological sites along southward-flowing tributaries of the Sabine River that contain Caddoan ceramics (Figure 16 and Table 4). In most cases, the number of sherds on each of the sites is rather low, and the density of sherds per $\mathrm{m}^{2}$ in excavations is also low $\left(<10\right.$ sherds per $\mathrm{m}^{2}$ ). However, Gray's Pasture site has one of the larger prehistoric Caddoan ceramic assemblage in thc South Hallsville mine area (see Table 4). In terms of the density of ceramics per $\mathrm{m}^{2}$, the density value of 60.3 sherds per $\mathrm{m}^{2}$ in the NETAS excavations is eclipsed only by $41 \mathrm{HS} 254$ on Hatley Creek (see LaVardera 1983a), where the density is 111.4 sherds per $\mathrm{m}^{2}$.

Whilc prehistoric sites with ceramics occur in a variety of settings and drainages in the South Hallsville mine area, the sites with the largest ceramic assemblage and the densest amounts of ceramics are found only on Hatley Creek and Clark's Creek, and on these streams, the sites are well-spaced at $1-2 \mathrm{~km}$ intervals (see Figure 16). These sites-including $4 \mathrm{IHS} 74,41 \mathrm{HS} 117,41 \mathrm{HS} 144,41 \mathrm{HS} 254,41 \mathrm{HS} 282$, and 41HS489--appear to be permanent settlements with middens, structures, burials, and small cemeteries, and they probably represent farmsteads and small hamlets (cf. Perttula and Cruse 1997). Another site, the Lane Mitchell Farm (41HS4) on Hatley Creek (see Figure 16) has four mounds that covered burned structures, and the brushed and engraved ceramics suggest it was occupied after ca. A.D. 1350 (cf. Thurmond 1990:22). 


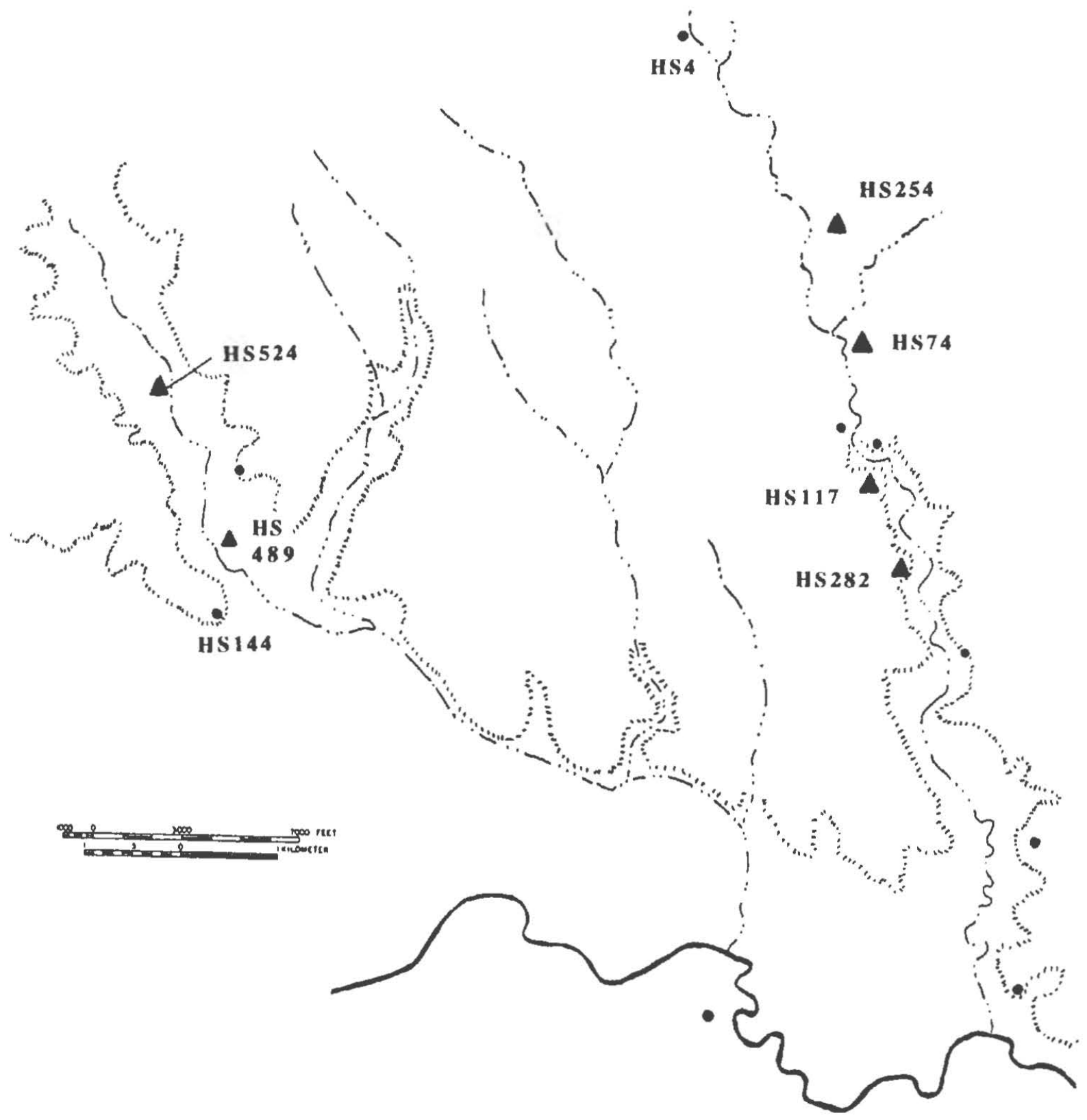

Figure 16. Caddoan sites with high densities of ceramics in the South Hallsville Mine area, including Gray's Pasture (41HS524). 
Table 4. Aboriginal Ceramics from the South Hallsville Mine Area

\begin{tabular}{|c|c|c|c|c|c|c|}
\hline SITE* & Landform & Creek & $\begin{array}{l}\text { Total } \\
\text { sherds }\end{array}$ & $\begin{array}{l}\text { \# dec. } \\
\text { sherds }\end{array}$ & sherds $/ \mathrm{m}^{2}$ & Reference \\
\hline \multirow[t]{2}{*}{68} & 3 & 1 & + & $?$ & & Keller 1991 \\
\hline & & & 24 & - & .0 & Keller $1992 \mathrm{c}$ \\
\hline \multirow[t]{2}{*}{69} & 3 & 1 & + & $?$ & & Keller 1991 \\
\hline & & & 6 & 1 & 0.5 & Keller $1992 \mathrm{c}$ \\
\hline 74 & 3 & 1 & 14428 & 3178 & 31.4 & $\begin{array}{l}\text { Heartield, } \\
\text { Price \& } \\
\text { Greene } 1988\end{array}$ \\
\hline 117 & 1 & 1 & 159 & 85 & 39.8 & $\begin{array}{l}\text { LaVandera } \\
1984\end{array}$ \\
\hline 138 & 3 & 2 & 44 & 18 & 4.0 & $\begin{array}{l}\text { Voellinger et } \\
\text { al. } 1984\end{array}$ \\
\hline \multirow[t]{2}{*}{140} & 1 & & + & $?$ & $?$ & Keller 1991 \\
\hline & & & 3 & - & .2 & Keller $1992 \mathrm{c}$ \\
\hline \multicolumn{7}{|l|}{$142 /$} \\
\hline \multirow[t]{2}{*}{143} & 3 & 2 & + & $?$ & $?$ & Keller 1991 \\
\hline & & & 24 & 1 & 1.8 & Keller 1992c \\
\hline 143 & 3 & 2 & 1 & - & N/A & $\begin{array}{l}\text { Voellinger } \\
\text { et al. } 1984\end{array}$ \\
\hline 170 & 1 & $2 / 3$ & 9 & 2 & 0.8 & Keller 1993 \\
\hline 172 & 4 & 2 & + & $?$ & $?$ & Keller 1991 \\
\hline 189 & 2 & 1 & 4 & $\dot{2}$ & 0.7 & Keller 1995 \\
\hline 195 & 6 & $3 / 5$ & 5 & - & 0.1 & $\begin{array}{l}\text { Voellinger et } \\
\text { al. } 1984\end{array}$ \\
\hline 227 & 3 & 1 & 2 & - & 0.5 & $\begin{array}{l}\text { LaVardera } \\
\text { 1983b }\end{array}$ \\
\hline \multirow[t]{2}{*}{229} & 2 & 1 & 106 & 47 & 13.3 & $\begin{array}{l}\text { LaVardera } \\
1983 b \text {. }\end{array}$ \\
\hline & & & + & + & $?$ & $\begin{array}{l}\text { LaVardera } \\
1983 c\end{array}$ \\
\hline 254 & 3 & 1 & 891 & 369 & 111.4 & $\begin{array}{l}\text { LaVardera } \\
\text { 1983a }\end{array}$ \\
\hline 264 & 3 & $1 / 4$ & 1 & - & 0.2 & $\begin{array}{l}\text { Voellinger et } \\
\text { al. } 1984\end{array}$ \\
\hline 267 & 3 & 2 & 15 & 2 & N/A & $\begin{array}{l}\text { Voellinger et } \\
\text { al. } 1984\end{array}$ \\
\hline 282 & 2 & 1 & 513 & 172 & 52.1 & $\begin{array}{l}\text { LaVandera } \\
1985\end{array}$ \\
\hline \multirow[t]{2}{*}{416} & 1 & 1 & 1 & - & 1.3 & Keller 1990 \\
\hline & & & 15 & - & 1.9 & Keller $1992 b$ \\
\hline 447 & 1 & 1 & 2 & - & 0.09 & Keller 1991 \\
\hline 466 & 4 & 6 & 1 & - & 0.1 & Keller 1994 \\
\hline 469 & 4 & $3 / 4$ & 24 & 2 & 0.9 & Keller 1994 \\
\hline 470 & 1 & 6 & 2 & - & 0.1 & Keller 1994 \\
\hline \multirow[t]{2}{*}{473} & $1 / 2$ & 1 & + & $?$ & $?$ & Keller 1991 \\
\hline & & & 6 & - & 1.5 & Keller $1992 \mathrm{c}$ \\
\hline \multirow[t]{2}{*}{476} & 2 & 1 & + & $?$ & $?$ & Keller 1991 \\
\hline & & & 5 & - & 0.6 & Keller 1992c \\
\hline
\end{tabular}


Table 4. Aboriginal Ceramics from the South Hallsville Mine Area, cont.

\begin{tabular}{lllllll}
\hline SITE* & Landform & Creek & $\begin{array}{l}\text { Total } \\
\text { sherds }\end{array}$ & $\begin{array}{l}\text { \# dec. } \\
\text { sherds }\end{array}$ & sherds $/ \mathrm{m}^{2}$ & Reference \\
\hline 477 & 2 & 1 & + & $?$ & $?$ & Keller 1991 \\
& & & 3 & - & 0.3 & Keller 1992c \\
488 & 1 & 3 & 122 & 19 & 8.0 & Keller 1993 \\
489 & 1 & 3 & 1011 & 435 & 48.2 & Keller 1993 \\
493 & 5 & 2 & 15 & - & 0.8 & Keller 1993 \\
501 & 6 & 3 & 3 & - & 0.3 & Keller 1993 \\
515 & 1 & 3 & 45 & 8 & N/A & Keller 1993 \\
524 & 3 & 3 & 85 & 4 & 22.7 & Keller 1992a, \\
& & & 2352 & 551 & 60.3 & 1993 \\
& & & & & & this paper
\end{tabular}

Key: Landform: 1, narrow finger ridge; 2 , knoll; 3 , terrace; 4, broad ridge nose; 5 , basal slope of ridge; 6 , crest of ridge. Creek: 1, Hatley Creek; 2, Rogers Creek; 3, Clarks Creek; 4, Sabine River; 5, Hardin Creek; 6, unnamed stream.

$+=$ present, but not quantified

?=unknown

Of these Caddoan sites with abundant ceramics, the Gray's Pasture assemblage is quite different than the others, in that the latter have abundant sherds from brushed and brushed-incised utility vessels, engraved ladders and scrolls (Haley Engraved, Carmel Engraved, and Maddox Engraved examples), cross-hatched incised bowls and jars, and some appliqued and pinched decorations; one site (41HS74) apparently has an engraved rattlesnake vessel, and these have been found at several Middle Caddoan sites in the Sabine River basin (see Perttula and Cruse 1997), including Oak Hill Village (Perttula 1999b). They also have Perdiz arrow points. These other high-density Caddoan ceramic sites along Hatley and Clark's creek appear to date to the Middle Caddoan period, and comprise part of a Middle Caddoan community. By contrast, Gray's Pasture has very little brushed pottery, abundant incised and punctated vessels, some sherds that resemble Crockett Curvilinear Incised and Pennington Punctated Incised, and engraved sherds with primarily horizontal and diagonal decorative elements.

\section{Temporal Estimates of Caddoan Ceramic Assemblages}

Ceramic assemblages from 16 other Caddoan assemblages, besides the Gray's Pasture site, in the middle reaches of the Sabine River basin (Figure 17) are used to develop a percentage frequency seriation (see Lyman et al. 1998:240-242) of ceramic decorative methods, including appliqued, brushed, engraved, incised, punctated-incised, and punctated methods (Table 5). As Dunnell (1970:310) notes, the ordering produced during the seriation "are strictly formal orders...They must be inferred to be chronologies." Judging the success of the ordering in a frequency seriation simply involves a determination if each category of seriated materials (i.e., types, decorative elements, etc.) has a continuous distribution and a unimodal frequency distribution (Lyman et al. 1998:242). 


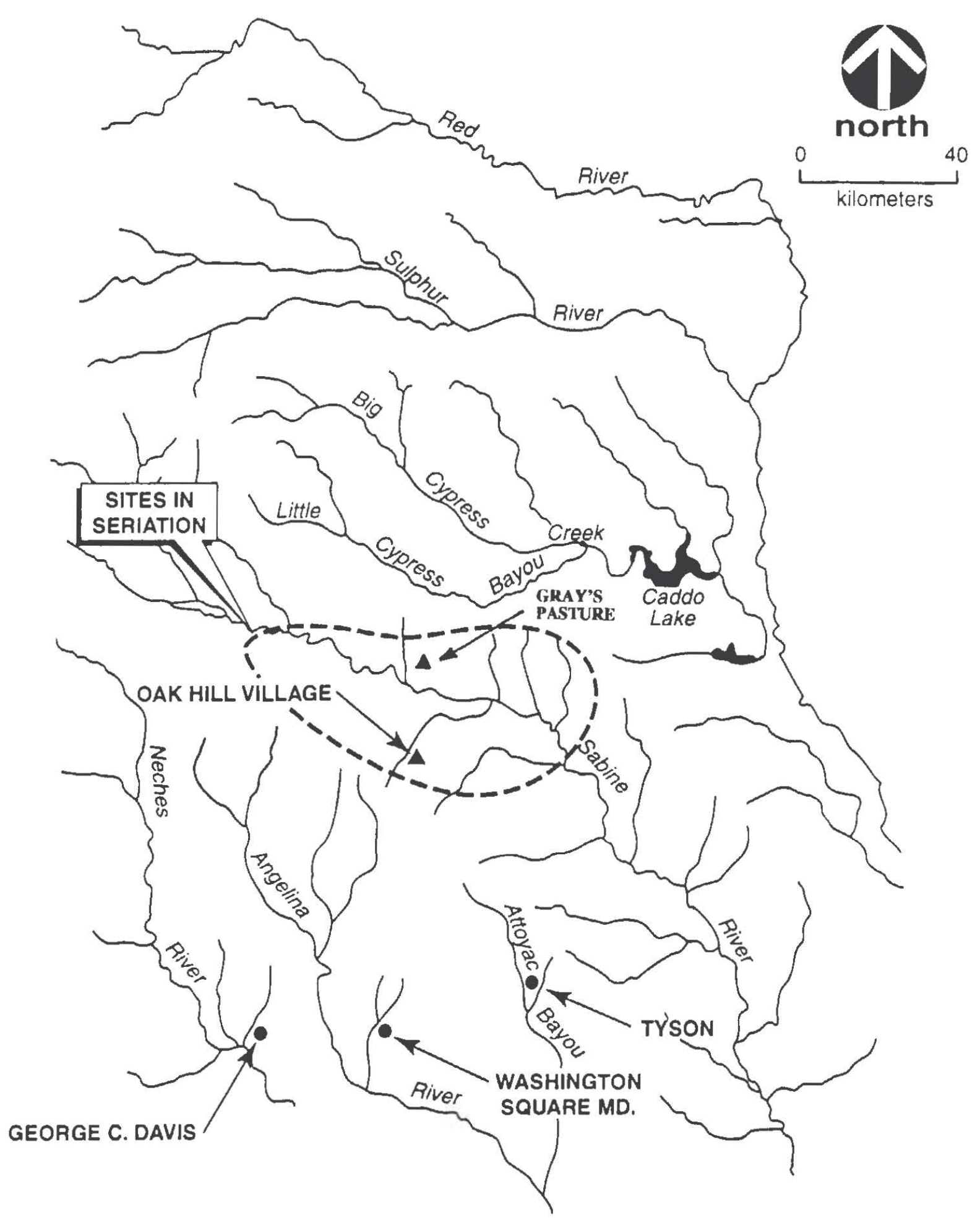

Figure 17. Area of Caddoan sites in the middle reaches of the Sabine River used for temporal comparisons with the Gray's Pasture site. Note locations of other important Early and Middle Caddoan settlements. 
Table 5. Frequency of Decorative Methods in selected middle Sabine River sites

\begin{tabular}{|c|c|c|c|c|c|c|}
\hline Site & $A^{*}$ & $\mathrm{~B}^{*}$ & $\mathrm{E}^{*}$ & $I^{*}$ & P-I* & $\mathrm{P}^{*}$ \\
\hline \multicolumn{7}{|l|}{ Group I } \\
\hline 41HS144 & 0.7 & 80.0 & 12.5 & 0.3 & 0.7 & 5.8 \\
\hline 41HS574\# & 1.7 & 76.1 & 8.4 & 3.4 & 0.0 & 10.2 \\
\hline 41 HS489 & 0.0 & 75.3 & 4.4 & 9.4 & 1.8 & 9.0 \\
\hline \multicolumn{7}{|l|}{ Group II } \\
\hline 41 RK240 & 0.0 & 48.7 & 12.8 & 4.8 & 10.2 & 17.7 \\
\hline 41RK19 & 0.0 & 45.5 & 7.2 & 16.0 & 12.0 & 18.1 \\
\hline 41SM55 & 0.1 & 37.7 & 6.6 & 20.8 & 5.5 & 27.1 \\
\hline $41 \mathrm{SM} 193$ & 0.0 & 35.5 & 22.6 & 13.4 & 7.0 & 20.4 \\
\hline 41HS74 & 1.9 & 28.7 & 22.8 & 20.2 & 6.9 & 19.3 \\
\hline 41RK214, D & 1.8 & 26.7 & 18.6 & 18.6 & 11.2 & 26.2 \\
\hline \multicolumn{7}{|l|}{ Group III } \\
\hline 41RK242\# & 0.0 & 24.4 & 18.0 & 3.8 & 15.4 & 33.3 \\
\hline $41 \mathrm{RK} 214, \mathrm{~B}$ & 2.2 & 22.6 & 9.1 & 19.4 & 8.3 & 28.2 \\
\hline 41RK214, C & 1.2 & 19.2 & 13.8 & 15.0 & 7.8 & 35.6 \\
\hline 41 RK214, G & 1.0 & 16.8 & 18.8 & 19.9 & 1.6 & 34.7 \\
\hline 41 RK214, St. 5 & 1.1 & 16.1 & 5.3 & 18.2 & 7.6 & 43.7 \\
\hline $41 \mathrm{RK} 243$ & 0.0 & 15.3 & 27.3 & 14.0 & 6.0 & 37.3 \\
\hline \multicolumn{7}{|l|}{ Group IV } \\
\hline 41HS488\# & 0.0 & 5.3 & 15.8 & 21.1 & 0.0 & 57.9 \\
\hline 41RK342 & 0.5 & 4.0 & 17.1 & 44.3 & 8.0 & 26.7 \\
\hline $41 \mathrm{HS} 524$ & 0.0 & 3.7 & 17.2 & 44.5 & 8.2 & 26.5 \\
\hline 41PN14 & 0.0 & 3.0 & 14.9 & 41.5 & 6.9 & 40.6 \\
\hline 41HS138\# & 0.0 & 0.0 & 11.1 & 33.3 & 16.7 & 38.9 \\
\hline
\end{tabular}

* Percentage of decorated sherds; A=appliqued; B=brushed; E-engraved; I=incised; P-I, punctated-incised; P=punctated

\# assemblages with less than 200 sherds

Sources: Texas Archeological Research Laboratory files, Harrison County; Perttula and Nelson 1997; Keller 1993; Pertula 2000; Clark and Ivey 1974; Walters and Haskins 2000; Walters et al. 1998; Heartfield, Price, and Greene 1988; Perttula 1999a; Sherman et al. 1998; Glander and Victor 1984; Voellinger et al. 1984

Taking into account the fact that there are wide ranges in the numbers of decorated sherds in the different assemblages considered here, and the case of the appliqued sherds that are uniformly rare in prehistoric Caddoan sites on the middle Sabine River, we may first note that there is a continuous distribution of the decorative methods in the percentage frequency seriation. This in itself is to be expected because of the decision to depict broad ceramic stylistic trends by employing decorative methods rather than decorative elements. To attempt a classification utilizing only decorative elements or identifiable rim and body patterns (cf. Schambach et al. n.d.)--or at least an approach based on the recognition of decorative elements--would only be feasible with a comparable reanalysis of the other sites 
because insufficient descriptions and illustrations of the decorated sherds from these sites have been provided in the published reports.

Only the percentage of brushed sherds in the seriation has a unimodal frequency distribution (see Table 5). The other decorative methods do not have unimodal distributions, however. Simply considering the proportions of brushed ceramics for the moment, the tentative frequency seriation places the Gray's Pasture ceramic assemblages comfortably in the lower end of the assemblage order, with other assemblages that have low frequencies of brushed ceramics (but some quantity of Crockett Curvilinear Incised, Pennington Punctated Incised, and other Early Caddoan decorated sherds), and many other assemblages above it in the order that conversely have much higher frequencies of brushed ceramics.

The many radiocarbon dates from Oak Hill Village (Rogers and Perttula 1999) indicate that the principal Caddoan occupation occurred between ca. A.D. 1150-1400. Differences in the radiocarbon dates and stylistic changes in the decorated ceramics suggest that Structure Group D at Oak Hill Village is estimated to date from ca. AD 1340-1400; Structure Group B between ca. A.D. 1275-1350; Structure Group C dates from ca. AD 1250-1340; Structure Group G dates between ca. A.D. 1150-1320; and Structure 5 dates from ca. A.D. 1275-1325 (Perttula 1999b:Figure 108).

Radiocarbon dates of the assemblages other than those from Oak Hill Village are not particularly useful in further evaluating the correctness of the order, because only 41HS74, 41SM55, 41SM193, and 41RK342 have dates, and each has only one assay per site. The calibrated age ranges (at one sigma) of the one date from 41SM193 are AD 13121350 ( 0.49 relative area under probability distribution [RA 3 and $\mathrm{AD} 1388-1423$ (0.51 RA); for 41 SM55, the age ranges are AD 1345-1391 (0.71 RA) and AD 1297-1317 (0.29 RA); for 4IRK342, the age ranges are AD 1307-1357 (0.64 RA) and AD 1382-1409 (Sherman et al. 1998); and the one calibrated date from 4IHS74 is AD 1159-1520 (0.87 RA). If both the seriation and the few calibrated radiocarbon dates are in the correct order, then this would suggest that not only that these sites are contemporaneous with Oak Hill Village based on the general range of the Oak Hill Village calibrated dates of AD 1150-1400+, but that the frequency of brushed ceramics on contemporaneous Caddoan sites in the middle Sabine River basin can range from as low as $4 \%$ to as high as $32 \%$.

1 cannot support this interpretation of the assemblage seriation/radiocarbon associations. First, it is based on extremely limited radiocarbon dating of individual components, and without a robust sample of radiocarbon dates from individual components that can establish discrete age ranges, these associations are probably spurious. Unfortunately, well-dated Caddoan components are few and far between in East Texas, the Middle Caddoan period being no exception. Second, the radiocarbon assay from 41HS74 has a standard deviation of 243 years, and thus the date is unreliable. Finally, this interpretation calls for the rejection of the findings of many ceramic analyses in East Texas that have convincingly demonstrated that brushed ceramics increasingly dominate the assemblages of Middle and Late Caddoan sites in several river and creek basins, including the Sabine River, with the brushed utility wares coming to dominate the decorated ceramics of many of (but not all) the Late Caddoan groups in the region (cf. Fields 1995; Middlebrook 1994; Perttula et al. 1998; Thurmond 1990).

That the percentage frequencies of the decorative methods do not have unimodal distributions is suspected to be the product of the gross nature of the seriation itself. That is, employing broadly defined classes such as engraved, incised, or incised-punctated does not permit the recognition of stylistic and temporal trends within each of the classes that could refine the ordering in the seriation. It is quite likely, then, that the seriation shown in 
Table 5 represents a conflation of useful decorative elements and modes within the various decorative methods (i.e., certain decorative elements within the incised-punctated sherds, for example, may be more popular than others at particular times, but failing to separate them out in the seriation probably means that there would be little overall change in the percentages of incised-punctated sherds as a whole).

Nevertheless, there are interesting trends among the different assemblages in the seriation of ceramic decorative methods that may be temporally-related, even though the ordering is not unimodal. With the increasing frequency of brushed sherds (ranging from $75-80 \%$ in Group I assemblages), the frequencies of all other decorative methods are lowered accordingly; the changes in decorative styles are not linear, however:

a. Incised sherds are most common in Group IV assemblages (see Table 5), with roughly comparable numbers of punctated sherds and low amounts of punctated-incised sherds;

b. In Group III assemblages, punctated sherds are at least twice as common as incised decorations, but the frequency of punctated-incised sherds remains about the same as in Group IV, with the exception of 41RK242;

c. Among the Group II assemblages, punctated-incised decorations have increased from a range of $1.6-8.3 \%$ in Group III (excluding the small sample from $41 \mathrm{RK} 242$ ) to a range of 5.5-12.0\%, and punctated sherds have become less frequent. In Group IV assemblages, for instance, incised and punctated sherds comprised between $71-82 \%$ of the decorated sherds, but only account for $22.5-47.9 \%$ of the decorated sherds in Group I1, and less than $19 \%$ in Group I; and

d. Group I assemblages have low or very low frequencies of incised, punctated-incised, and punctated sherds, clearly indicating a major change in how bowls and jars are being decorated in the middle Sabine River basin. The frequency distribution data also signal the rising importance of the brushed cooking jar in these Caddoan ceramic assemblages.

I suggest that these broad trends in the proportions of decorated sherds have temporal significance, with the Group IV assemblages, including the Gray's Pasture site, being the earliest in the seriation, and the Group I assemblages being the youngest. Further, based on changes in the relative frequency of the decorated sherds in the welldated Oak Hill Village site (with the site's ceramic assemblages falling in Groups II and III in the seriation; see Table 5), and the radiocarbon data, Groups II and III assemblages probably date between ca. A.D. 1150/1200-1400+, with Group I ceramic assemblages in the seriation dating after A.D. 1400 (how much after A.D. 1400 is unknown), and the Group IV assemblages probably dating between ca. A.D. 1000 and A.D. 1150/1200 or thereabouts. It will be important in future analyses of Caddoan ceramic assemblages in the middle Sabine River basin to build more refined seriations of decorated sherds employing: (a) comparable decorative elements and (b) decorative methods, accompanied by a series of radiocarbon dates from well-controlled contexts. 


\section{CONCLUSIONS}

The ceramics from the Gray's Pasture site are locally and regionally distinctive. If the information on ceramic decorative methods and temporal estimates from radiocarbon dating and a reconstruction of the occupational history of the Oak Hill Village are accurate, the Caddoan occupation at the Gray's Pasture site dates to the Early Caddoan period, ca. A.D. 1000-1200, as defined by Story (1990). Certainly the occurrence of a number of incised-punctated sherds at the site that resemble Crockett Curvilinear Incised and Pennington Punctated Incised is temporally consistent with this age estimate, and further suggests there may have been contact and interaction between the Caddoan community at Gray's Pasture and contemporaneous Early Caddoan mound centers, such as the HudnallPirtle site (41RK4, see Bruseth 1991), about $8.8 \mathrm{~km}$ to the southeast.

Early to Middle Caddoan settlements with abundant ceramics are rather equally spaced along Clark's and Hatley creeks in this part of the middle Sabine River basin (see Figure 17), but Area IV at the Gray's Pasture site appears to be the earliest Caddoan settlement in this locale, except for 41HS488 about $1 \mathrm{~km}$ to the southeast, and some evidence of Early Caddoan use of 41HS74 on Hatley Creek (Heartfield, Price, and Greene, Inc. 1988). The post-A.D. 1200 Caddoan settlement of the South Hallsville mine area is extensive, and sites are marked by midden deposits, structures, and small cemeteries, and Middle Caddoan mounds are also part of the larger community. The Gray's Pasture, although functionally comparable to these other residential settlements (i.e., perhaps a small hamlet or a series of farmsteads) was apparently abandoned about the time that Middle Caddoan populations began to make intensive use of the middle reaches of the Sabine River basin.

\section{REFERENCES CITED}

Brown, J. A.

1996 The Spiro Ceremonial Center: The Archaeology of Arkansas Valley Caddoan Culture in Eastern Oklahoma. 2 Vols. Memoirs No. 29. Museum of Anthropology, University of Michigan, Ann Arbor.

Bruseth, J. E.

1991 Hudnall-Pirtle Site: An Early Caddoan Mound Complex in Northeast Texas. Caddoan Archeology Newsletter II(3):9-15.

Clark, J. W. and J. E. Ivey

1974 Archeological and Historical Investigations at Martin Lake, Rusk and Panola Counties, Texas. Research Report 32. Texas Archeological Survey, The University of Texas at Austin.

Dunnell, R. C.

1970 Seriation Method and Its Evaluation. American Antiquity 35:305-319.

Glander, W. P. and S. Victor

1984 Additional Cultural Resource Investigations at the Martin Lake Mine Tracts A, B, and C. Document No. 83718. Espey, Huston \& Associates, Inc. 
Heartfield, Price, and Greene, Inc.

1988 Data Recovery at Site 4lHS74. Heartfield, Price, and Greene, Inc., Monroe, Louisiana.

Hoffman, M. P.

1967 Ceramic Pipe Style Chronology along the Red River Drainage in Southwestern Arkansas. The Arkansas Archeologist 8(1):4-14.

Keller, J. E.

1990 A Cultural Resources Survey of Certain Portions of the South Hallsville Project for the Sabine Mining Company, Hallsville, Texas. Southern Archaeological Consultants, Inc.

1991 Archaeological Survey at the South Hallsville \#1 Mine, Harrison County, Texas 1991. Report of Investigations 12-91. Southern Archaeological Consultants, Inc.

1992a Excavations at the Gray's Pasture Site (41HS524). Caddoan Archeology Newsletter IIl (No. 4):26-28.

1992b Archaeological Investigations at the South Hallsville No. 1 Mine, Harrison County, Texas, July 1990 - January 1991. Southern Archaeological Consultants.

1992c Archaeological Testing at the South Hallsville No. 1 Mine, Harrison County, Texas, 1991. Report of Investigations 3-92. Southern Archaeological Consultants, Inc.

1993 Archaeological Survey and Testing at the South Hallsville No. 1 Mine, Harrison County, Texas 1992. Report of Investigations 3-93. Southern Archaeological Consultants, Inc., Harlingen.

1994 Archaeological Testing at the South Hallsville No. 1 Mine 1993. Report of Investigations 5-94. Southern Archaeological Consultants, Inc.

19951994 Archaeological Survey Operations at the South Hallsville No. 1 Mine, Harrison County, Texas. Report of Investigations 3-95. Southern Archaeological Consultants, Los Fresnos, Texas

LaVardera, L. T.

1983a Archaeological Testing at 41HS254, South Hallsville Project, Harrison County, Texas. North American Consultants, Inc., Dallas.

1983b Archaeological Testing at 41HS227 and 41HS229, South Hallsville Project, Harrison County, Texas. North American Consultants, Inc., Dallas.

1983c Cultural Resource Survey of the 1983 Proposed Bond Area and Associated Haul Roads at the South Hallsville No. 1 Mine, Harrison County, Texas. North American Consultants, Inc., Dallas.

1984 Archaeological Testing at Ten Prehistoric Sites Within the 1984-1985 Disturbance Area. North American Consultants, Inc., Dallas.

1985 Backhoe Trenching at 41HS282, South Hallsville Project, Harrison County, Texas. North American Consultants, Inc., Dallas. 
Lyman, R. L., S. Wolverton, and M. J. O’Brien

1998 Seriation, Superposition, and Interdigitation: A History of Americanist Graphic Depictions of Culture Change. American Antiquity 63(2):239-261.

Perttula, T. K.

1999a The Prehistoric and Caddoan Archeology of the Northeast Texas Pineywoods. In Prehistoric Archeology of Texas, edited by T. K. Perttula. Volume under review by Texas A\&M University Press, College Station.

1999b Decorated Ceramics. In The Oak Hill Village Site (41RK214), Rusk County, Texas, by R. Rogers and T. K. Perttula, pp. 237-349. 3 Vols. PBS\&J, Inc., Austin.

2000 The Analysis of Caddoan Ceramics from Four Sites in Rusk County, Texas. MS on file, PBS\&J, Inc., Austin.

Perttula, T. K. and J. B. Cruse

1997 The Caddoan Archaeology of the Sabine River Basin during the Middle Caddoan Period. Journal of Northeast Texas Archaeology 9:30-37.

Perttula, T. K. and B. Nelson

1997 41 HS574, the Coleman Farm Site on Starkey Creek. Journal of Northeast Texas Archaeology 10:52-57.

Perttula, T. K., M. Tate, H. Neff, J. W. Cogswell, M. D. Glascock, E. Skokan, S. Mulholland, R. Rogers, and B. Nelson

1998 Analysis of the Titus Phase Mortuary Assemblage at the Mockingbird or "Kahbakayammaahin" Site (41TT550). Document No. 970849. Espey, Huston \& Associates, Inc., Austin.

Rogers, $\mathbf{R}$.

1999 Ceramic Pipes, Daub, and other Clay Objects. In The Oak Hill Village Site (4lRK214), Rusk County, Texas, by R. Rogers and T. K. Perttula, pp. 371-383. 3 Vols. PBS\&J, Inc., Austin.

Rogers, R. and T. K. Perttula

1999 The Oak Hill Village Site (41RK214), Rusk County, Texas. 3 Vols. PBS\&J, Inc., Austin.

Schambach, F. F., A. M. Early, and J. C. Weber

n.d. Typology and Nomenclature for South Arkansas Ceramics: The Descriptive Classification. MS on file, Arkansas Archeological Survey, Fayetteville.

Sherman, D. L., M. A. Nash, T. K. Perttula, G. S. Greene, E. A. S. Switek, and R. M. Rogers

1998 National Register Testing of Five Cultural Resource Sites in the Oak Hill D-III Permit Area, Rusk County, Texas. Document No. 971091. Espey, Huston \& Associates, Inc., Austin.

Story, D. A.

1990 Cultural History of the Native Americans. In The Archeology and Bioarcheology of the Gulf Coastal Plain, by D. A. Story, J. A. Guy, B. A. Burnett, M. D. Freeman, J. C. Rose, D. G. Steele, B. W. Olive, and K. J. Reinhard, pp. 163-366. 2 Vols. Research Series No. 38. Arkansas Archeological Survey, Fayetteville. 
Suhm, D. A. and E. B. Jelks (editors)

1962 Handbook of Texas Archeology: Type Descriptions. Special Publication No. 1, Texas Archeological Society, and Bulletin No. 4, Texas Memorial Museum, Austin.

Thurmond, J. P.

1990 Archeology of the Cypress Creek Drainage Basin, Northeastern Texas and Northwestern Louisiana. Studies in Archeology 5. Texas Archeological Research Laboratory, The University of Texas at Austin.

Voellinger, L. R., T. D. Hayes, and M. W. Voellinger

1984 The Cultural Resources Investigations of the Henry W. Pirkey Power Plant and South Hallsville Lignite Mine Transportive Systems Reroute, Harrison County, Texas. Document No. 83434. Espey, Huston \& Associates, Inc., Austin.

Vogel, J. C., A. Fuls, E. Visser, and B. Becker

1993 Pretoria Calibration Curve for Short Lived Samples. Radiocarbon 35(1):73-86.

Walters, M. and P. Haskins

2000 The Bryan Hardy Site (41SM55), Smith County, Texas. Journal of Northeast Texas Archaeology 12:1-26.

Walters, M., P. Haskins, D. H. Jurney, S. E. Goldborer, and T. K. Perttula

1998 Archaeological Investigations at the Redwine Site (41SM193), Smith County, Texas. Journal of Northeast Texas Archaeology 11:1-38. 